Bionomina, 22: 8-38 (2021)

$\mathrm{https://www.mapress.com/j/bn}$

Copyright (C) 2021 • Magnolia Press
Article

\section{BIONOMINA}

https://doi.org/10.11646/bionomina.22.1.2

http://zoobank.org/urn:lsid:zoobank.org:pub:AA276A71-2D14-40E6-8BC9-CC47F5993EF7

\title{
Eponyms as scientific recognition to Queen Astrid and King Leopold III of Belgium
}

\author{
Yves SAmYN ${ }^{1,3} \&$ Jackie L. VAN Goethem ${ }^{2}$ \\ ${ }^{1}$ Scientific Heritage Service, partim Recent Invertebrates Collections, Royal Belgian Institute of Natural Sciences, \\ Vautierstraat 29, B-1000 Brussels, Belgium. \\ ${ }^{2}$ King Leopold III Fund for Nature Exploration and Conservation, Royal Belgian Institute of Natural Sciences, Vautierstraat \\ 29, B-1000 Brussels, Belgium. !'jackie.vangoethem@naturalsciences.be; ○ https://orcid.org/0000-0002-6921-3632 \\ ${ }^{3}$ Corresponding author: "yves.samyn@naturalsciences.be; @ ittps://orcid.org/0000-0002-1653-3018
}

\begin{abstract}
This contribution provides an annotated list of taxa named after Queen Astrid and King Leopold III of Belgium, including the time they were Crown Prince Leopold and Princess Astrid of Belgium. The list was compiled by searching online nomenclators as well as 'logical' publications in which taxonomists would have published taxa named in honour of Leopold III and Astrid. In total, we discovered 144 scientific names that are based on the name of Leopold III and 26 that honour Astrid. Moreover, serendipitously we found several eponyms given to cultivars which we document only in an incidental way. The compiled impressive number of eponyms demonstrates the recognition of members of the scientific community towards the efforts of the Belgian Royal Household in the exploration and conservation of biodiversity. The legacy of Leopold III lives on in the King Leopold III Fund for Nature Exploration and Conservation. The workings and achievements of the latter organization are here also briefly detailed.
\end{abstract}

\section{Key words}

Biodiversity, nomenclature, name-bearing, types, nature conservation.

\section{Introduction}

Samyn \& De Clerck (2012) argued that the value of scientific names "exceeds the field of biology sensu stricto" because they matter for society. For instance, the international legislation that controls the trade of endangered species (CITES) ${ }^{1}$, just as the Convention on Migratory Species (CMS) ${ }^{2}$ and the Convention on Biological Diversity (CBD) ${ }^{3}$ and its associated Access and Benefit Sharing Protocol (ABS) also known as the Nagoya Protocol ${ }^{4}$ use species names as currency. Knapp et al. (2004) argued earlier in a similar way when they wrote: "Names, however, have always been important. In the classical, pre-Linnaean past, the correct application of the names for medicinal plants could mean the difference between life and death. This need for stability in names of important organisms or concepts was in part the basis for the copying and recopying of the classical works of early scholars such as Dioscorides or Theophrastus through the Middle Ages in Europe." 
Scientific names have to be constructed in accordance with the ruling codes of nomenclature. For zoological taxa this is the International Code of Zoological Nomenclature (here cited as 'the

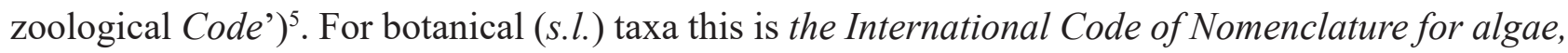
fungi, and plants (ICN) ${ }^{6}$. For bacterial taxa (s.l.) this is the International Code of Nomenclature of Prokaryotes (ICNP) ${ }^{7}$. For cultivated plants this is the International Code of Nomenclature for Cultivated Plants (ICNCP) ${ }^{8}$. For plant associations or communities this is the International Code of Phytosociological Nomenclature (ICPN) ${ }^{9}$. For viruses, the International Code of Virus Classification and Nomenclature (ICVCN) ${ }^{10}$ applies. For minerals, nomenclature follows the Commission on New Minerals, Nomenclature and Classification (CNMNC) ${ }^{11}$. These Codes differ from one another in several aspects, but they have the unifying principle that scientific names should at all times be unique and stable, published, and backed-up by voucher specimens, which should, or should preferably, be deposited in publicly available collections. In this way, a nomenclatural Tower of Babel that would obstruct efficient communication on the taxa is avoided. Samyn et al. (2010) stated this for zoological taxa, but it seemingly applies to the whole of the nomenclature of natural history.

Scientific names can be eponyms. Eponyms, as the word eponym is derived from the ancient

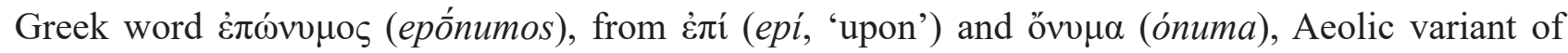
óvo $\mu \alpha$ (ónoma, 'name'), are scientific names that are 'named after'. The present contribution will not treat eponyms attributed to anatomic structures, diseases, injuries, etc. (Hunter et al. 2000) nor will it deal with eponyms named after geographical places such as seas, islands or cities. Instead, this paper will highlight the predominantly zoological taxa named after Prince/King Leopold III of Belgium (Leopold III hereafter) and his first spouse Princess/Queen Astrid of Belgium (Astrid hereafter) and this to mark their importance in nature conservation, worldwide, an engagement that continues to live on in the legacy of Leopold III, through the King Leopold III Fund for Nature Exploration and Conservation $^{12}$ (KLFNEC).

This Fund was founded by Leopold III in 1972, 11 years before he passed away. Its main purpose was and is to aid and accelerate biodiversity research outside Europe. Anthropological study of nonEuropean peoples living in close contact with nature is also favoured. In financing field work done by researchers and $\mathrm{PhD}$ students associated with Belgian universities and scientific institutions, the Fund contributes annually to around 15 expeditions. Up to now more than 400 expeditions have been cofinanced with grants generally ranging from 1,000 to 4,000 euros. The main output of these are $\mathrm{PhD}$ theses and scientific papers, the latter exceed by now largely 1,500 titles; references of which can be found on the dedicated website of the King Leopold III Fund ${ }^{12}$.

During two decades (1976-1996), the KLFNEC contributed substantially to the pioneering biological research station on Laing Island, located in Hansa Bay on the North coast of Papua New Guinea. In 1977, this station was named King Leopold III Biological Station Laing Island (KLBSLI). Marine and terrestrial fauna and flora was thoughtfully collected and is still being studied by Belgian and foreign researchers, the output by scientific papers being already well over 600 titles. The history and highlights of the KLBSLI have recently been detailed by authors in Van Goethem \& Samyn (in press).

\section{Material and methods}

Eponyms honouring Leopold III and Astrid were searched through different methods.

Potential zoological eponyms were searched through the Index to Organism Names (ION) ${ }^{13}$ that extracts its names from the Zoological Record ${ }^{14}$. We entered 'leopold*' and 'astrid*'15 as search terms. The names retrieved by this modus were located in the literature and were checked to ascertain 
that they were indeed eponyms in honour of the desired royalties and not to other people (e.g. King Leopold I or II of Belgium, American ecologist Aldo Leopold, Leopold Madani, etc.). We did the same with search terms such as 'principalis', 'regis' and 'regina'.

Potential zoological eponyms were also searched through direct query of the digital version of the Zoological Record (from 1972 to 2014), as available at the Royal Museum of Central Africa ${ }^{16}$ and through systematically screening of the in-house publications of the 'logical' institutions wherein the material recovered by Leopold III and Astrid would have been described, being the publications of the Royal Belgian Institute of Natural Sciences in Brussels ${ }^{17}$ and the Royal Museum of Central Africa in Tervuren ${ }^{18}$. In the latter exercise we paid attention not only to taxa holding 'leopold' or 'astrid' in their name, but also related terms such as 'regis' and 'regina'.

Potential botanical eponyms were searched through the International Plant Names Index (IPNI) ${ }^{19}$ by entering 'leopold*' and 'astrid*' as search terms. As with the zoological names discovered this way, we checked them as much as possible against the publications in which they appeared in order to ascertain desired eponymy and, in addition, we screened the in-house publications of the 'logical' institutions wherein the material recovered by Leopold III and Astrid would have been described, being the publications of the Meise Botanic Garden, Belgium ${ }^{20}$.

Potential fungal eponyms were searched through consulting the Index Fungorum ${ }^{21}$ by entering the epithets 'leopold*' and 'astrid*' as search criteria. The recovered taxon names were then screened for validity of the searched for eponymy by checking the publications in which they appeared through systematically screening of the in-house publications of the 'logical' institutions wherein the material recovered by Leopold III and Astrid would have been described, being the publications of Meise Botanic Garden, Belgium ${ }^{20}$.

Potential algal eponyms were searched through Algae Base ${ }^{22}$, the Index Nominum Algarum ${ }^{23}$ and the on-line DiatomBase ${ }^{24}$ again by entering 'leopold*' and 'astrid*', with and without the '*' wildcard, as search items. Here again, recovered taxon names were looked up as much as possible in original publications so as to verify as if they were established in honour of the persons here concerned.

We screened the International Mineralogical Associations' list of minerals through the website of the Commission on New Minerals, Nomenclature and Classification ${ }^{25}$, looking for names that could match Leopold III and Astrid.

We also searched the ICNCP ${ }^{26}$, the Azalea Society of America (ASA) ${ }^{27}$, the List of Cultivars Sempervivum and Jovibarba ${ }^{28}$, The International Register and Checklist of Cultivar Names in the Genus Syringa L. (Oleaceae) ${ }^{29}$, The International Rhododendron Register and Checklist, Second Edition Lem-Z. ${ }^{30}$, The Royal Horticultural Society Plant Finder ${ }^{31}$ and Dendrology online ${ }^{32}$ websites were also screened for names that could match Leopold III and Astrid., but only diagonally.

No searches for bacterial or viral taxa named after Leopold III and Astrid were carried out as we do not expect these to yield results.

Since this paper is not concerned with taxonomy s.S., we solely cite the scientific names as mentioned in the original publications.

Gradually, we are putting pictures, micro-CT scans and micro-CT models on dedicated digital platforms such as Virtual Collections Brussels (VCB) $)^{33}$ and Virtual Collections Tervuren (VCT) ${ }^{34}$ that can be searched online.

In what follows, eponymous names of species (specific epithets) are written as they were in the original work, in their original spelling, i.e. sometimes with a capital (e.g., Leopoldi) and sometimes without (e.g., astridae). In zoological nomenclature, the presence or absence of the capital does not carry a message regarding the grammatical status of the epithet, as it does in some cases (Frétey 2019). Anyway, nowadays, according to Article 28 of the zoological Code, an epithet must always begin with a lower-case letter, so those originally published with a capital initial must be corrected. Species-group names published as separate words that are deemed to form a single word are to be 
united according to Article 32.5.2.2, species-group names united by a hyphen must be united by removing the hyphen according to Article 32.5.2.3.

Hereby we designate as 'secondary eponym' a name derived from another name itself derived from the name of a person, such as the specific epithet astrida named after the city of Astrida, itself named after Princess Astrid.

Unavailable names (including nomina nuda) are presented here "between straight quotes".

The following abbreviations are used throughout the text:

\begin{tabular}{|c|c|}
\hline ABS & Access and Benefit Sharing \\
\hline ASA & Azalea Society of America \\
\hline AST & Asteroidea (register prefix used in RBINS) \\
\hline BR & Register prefix used in MBG \\
\hline CBD & Convention on Biological Diversity \\
\hline CITES & $\begin{array}{l}\text { Convention on the International Trade in Endangered Species of Wild Fauna and } \\
\text { Flora }\end{array}$ \\
\hline CMS & Convention on Migratory Species \\
\hline CNMNC & Commission on New Minerals, Nomenclature and Classification \\
\hline CNU & Collection number unknown or unattributed \\
\hline EVCT & Entomological Virtual Collections Type (register prefix used in RBINS) \\
\hline HET GEN & Heterocera General Collection (collection prefix used in RBINS) \\
\hline HET VPL & Heterocera Voyage Prince Leopold (collection prefix used in RBINS) \\
\hline ICN & International Code of Nomenclature for algae, fungi, and plants \\
\hline ICNCP & International Code of Nomenclature for Cultivated Plants \\
\hline ICNP & International Code of Nomenclature of Prokaryotes \\
\hline ICPN & International Code of Phytosociological Nomenclature \\
\hline ICRA & International Cultivar Registration Authority \\
\hline ICVCN & International Code of Virus Classification and Nomenclature \\
\hline I.G. & Inventaire Général (General Inventory Number, collection prefix used in RBINS) \\
\hline ION & Index to Organism Names \\
\hline INV & Register prefix used in the RBINS collection (INV: Invertebrates) \\
\hline IPNI & International Plant Name Index \\
\hline KLFNEC & King Leopold III Fund for Nature Exploration and Conservation \\
\hline KLBSLI & King Leopold III Biological Station Laing Island \\
\hline MBG & Meise Botanic Garden, Meise (Belgium) \\
\hline MNHN & Muséum National d'Histoire Naturelle, Paris (France) \\
\hline NHM & National History Museum, London (United Kingdom) \\
\hline NRM-ORTH & Naturhistoriska Riksmuseet Orthoptera Collections \\
\hline ORTH GEN & General Orthoptera Collection (collection prefix used in RBINS) \\
\hline PAP BEL & Papillons belges (collection prefix used in RBINS) \\
\hline PAP GEN & Papillons General Collection (collection prefix used in RBINS) \\
\hline PAP VRL & Papillons Voyage Prince Leopold (collection prefix used at RBINS) \\
\hline RBINS & Royal Belgian Institute of Natural Sciences, Brussels (Belgium) \\
\hline RMCA & Royal Museum for Central Africa, Tervuren (Belgium) \\
\hline TL & Type Locality (i.e., location where the type(s) was/were sampled) \\
\hline TD & $\begin{array}{l}\text { Type Data (i.e., nomenclatural status, institution where the type(s) is / are } \\
\text { deposited, eventual register number(s)) }\end{array}$ \\
\hline & United States National Museum, Washington (USA) \\
\hline VCB & Virtual Collections Brussels \\
\hline
\end{tabular}


VCT Virtual Collections Tervuren

VIVC Vitis International Variety Catalogue

\section{Results}

\section{Acquisitions}

Table 1 shows the main acquisitions for Belgian collections made by/through Leopold III \& Astrid. We have restricted ourselves to those acquisitions that we could retrieve via the archives and databases of the RBINS and the RMCA. This listing clearly shows that early focus (mid 1920's to early 1930's) shifted from the Belgian Congo to South-East Asia (Indonesia) (early 1930's) and to the rest of the world with particular attention to South America whereby the last acquisition of 1984 and at the same time the sole botanical acquisition is in honor as it is post mortem.

Below, we provide the eponyms named after Leopold III and Astrid that we recovered in different domains of biological classifications. Taxa, with their name as introduced in the original publications, are given in alphabetical order within every group. For each eponym, we provide type data (TD) in the form of the status, including their registration number (nr.) and the location of the type(s), as well as on the type locality (TL). Further metadata attached to these eponyms can be found in the original publications.

\section{Algal taxa}

Our searches on Algae Base, the Index Nominum Algarum and the on-line DiatomBase revealed no entries that had 'leopold' and more than 100 taxa that had 'astrid' in their name. Many of the latter proved supra-specific (e.g., Bigastridum, COELASTRIDAE, Desmastridion, Dinastridium, Euastridium, HydRoGASTRIDAE, etc.), albeit some specific names (e.g., Gomphomena astridae, Suriella astridae, etc.) were also found. However, after scrutinization of these names, none could be assigned as being eponymous to the royalties we searched for.

However, we found one taxon that was named after Leopold III while being Crown Prince, Duke of Brabant: Ostreobium brabantium Weber-Van Bosse, 1932.

\section{Green algae (Phylum CHLOROPHYTa)}

\section{Class ULVOPHYCEAE: order BRYOPSIDALES}

Ostreobium Brabantium Weber-Van Bosse, 1932. • TD: Syntypes RBINS I.G.9223/CHLO.001-002. • TL: Indonesia, Weim Island, Banda-Neira Island. • Remarks: [1] At first sight, the name of this species does not seem to be an eponym to Leopold III, but in Belgium the denomination of 'Duke of Brabant' is a dynastic title and is traditionally assigned to the oldest son of the sovereign. [2] According to recommendation 60F.1 of the botanical Code, the specific epithet of this name should be corrected in brabantium. 
TABLE 1. Overview of the main acquisitions for Belgian collections made by/through Leopold III and Astrid.

\begin{tabular}{|c|c|c|}
\hline Institution & Expedition & Nature of collected specimens \\
\hline RMCA & 1925, Belgian Congo & Spiders \& scorpions \\
\hline RMCA & 1926, Belgian Congo & A bat species \\
\hline RMCA & 1930, Belgian Congo & $\begin{array}{l}\text { Spiders \& mammals (ranging from shrews to antelopes and } \\
\text { even a hippopotamus) }\end{array}$ \\
\hline RBINS & $\begin{array}{l}\text { 1929, Indonesia, Papua (with some } \\
\text { additional limited records from Egypt, } \\
\text { Mauritius, China, Japan, Sri Lanka and } \\
\text { French Polynesia) }\end{array}$ & $\begin{array}{l}\text { Amphibians, echinoderms, corals, brachiopods, molluscs, } \\
\text { mammals, fish, reptiles, a single velvet worm new to science } \\
\text { and also a cave formation }\end{array}$ \\
\hline RBINS & 1930, Indonesia & Molluscs and a dugong \\
\hline RBINS & 1931, Indonesia & $\begin{array}{l}\text { A black coral, sponges, barnacles, moss animals, forams \& } \\
\text { molluscs }\end{array}$ \\
\hline RBINS & 1932, Belgian Congo & Molluscs \\
\hline RBINS & $\begin{array}{l}\text { 1932, Vietnam, Malaysia, Philippines and } \\
\text { Indonesia }\end{array}$ & Various taxa \\
\hline RBINS & 1933, Azores & Various taxa \\
\hline RBINS & 1933, Angola & Echinoderms \\
\hline RBINS & 1934, Angola & Crustaceans \\
\hline RBINS & 1934, Indonesia & Corals \\
\hline RBINS & 1942, Belgium & Squeleton of Equus caballus, arabian race of horse \\
\hline RBINS & 1962, Brazil & Vertebrates and one mollusc \\
\hline RBINS & 1964, Brazil & Invertebrates and vertebrates \\
\hline RBINS & 1966, Suriname & $\begin{array}{l}\text { Fish, amphibians, reptiles, mammals, insects and other } \\
\text { invertebrates }\end{array}$ \\
\hline RBINS & 1967, Brazil & Fish, amphibians and invertebrates \\
\hline RBINS & 1970, French Guyana & Fish, amphibians and invertebrates \\
\hline RBINS & 1972, Indo-Malaysia & Vertebrates and invertebrates \\
\hline RBINS & 1973, Yugoslavia & Invertebrates \\
\hline MBG & 1977, Bolivia & $\begin{array}{l}\text { Holotype of Spiranthera leopoldiana Bamps \& Robijns, } \\
1984\end{array}$ \\
\hline
\end{tabular}

\section{Botanical taxa}

Our searches on IPNI revealed over 300 entries that had 'leopold' and some 20 taxa that had 'astrid' in their name. However, after scrutinization of these names, only one single taxon returned as eponymous to one of the names we searched for, in casu: Spiranthera leopoldiana Bamps \& Robyns, 1984.

\section{Flowering plants (Phylum MAGNOLIOPHYTA)}

\section{Class Magnoliopsida (magnolias): order SAPINDALES}

Spiranthera leopoldiana Bamps \& Robijns, 1984. • TD: Holotype MBG BR0000008538840. • TL: Bolivia, Santa Cruz, Robore, San José. • Remarks: Picture of holotype available on the website of MBG/section botanical collections ${ }^{35}$; original description available on the same site ${ }^{36}$. 


\section{Fungal taxa}

Our searches on the Index Fungorum retrieved no taxa with variations of 'leopold' and/or 'astrid' in their names. However, through the collections database of the MBG, we found one taxon with astrid in its name: Dirina astridae Tehler, 2013 (described in Tehler et al. 2013). This taxon is however named after the daughter of the author of this taxon. In the same database we also found Reichlingia leopoldi Diederich \& Scheidegger, 1996, but this is a species dedicated to botanist Léopold Reichling from Luxemburg.

\section{Minerals}

Our searches on the IMA List of minerals through the website of the Commission on New Minerals, Nomenclature and Classification, with variations to 'leopold' and/or 'astrid' in their names were fruitless.

\section{Plant cultivars}

We perceived a plant cultivar named after Leopold III, actually purely by chance: Vitis vinifera 'Leopold III'. It is a grape variety of exceptional quality grown in Flemish Brabant (Belgium). Our curiosity was aroused and subsequent searches, mainly on the internet, revealed that many eponyms in the field of cultivars are dedicated to royals, most often nominal but also by title.

Going through the International Register and Checklist of Cultivar Names in the Genus Syringa L. (Oleaceae), we found four eponyms: Syringa vulgaris 'Prince Léopold', introduced by Klettenberg in 1930; Syringa vulgaris 'Léopold III', and its synonym Syringa vulgaris 'Leopold III', both introduced by Klettenberg in 1935; and Syringa vulgaris 'Reine Astrid', introduced by Klettenberg in 1935.

Other examples of eponyms in honour of Astrid and Leopold III are: Araucaria heterophylla 'Astrid' (synonym: Araucaria heterophylla 'Leopold Astrid') and Araucaria heterophylla 'Leopoldii', two of the several cultivars of the Norfolk pine. The latter variety was introduced in 1923 (see Dendrologie online $\left.^{32}\right)$.

Hydrangea macrophylla 'Leopold III', a variety of bigleaf hortensia, was introduced in 1938 by Emiel Draps from Strombeek (Belgium). At that time hortensias were the second most appreciated plants after the roses. The cultivar 'Leopold III' is a cross between the older cultivars 'Rosabella' and 'Merveille' (Pauwels \& Pieters 2011).

More cultivars are Sempervivum 'Leopold III', considered a synonym of Sempervivum 'Elfride' (see List of Cultivars Sempervivum 2000 ${ }^{37}$ ). Cultivars within this genus, commonly known as houseleeks, are in general not attached to a species. Via the Royal Horticultural Society plant finder we additionally found: Codiaeum 'Leopold III', a shrub with leathery leaves commonly called croton and belonging to the spurge family (EUPHORBIACEAE) as well as Cymbidium 'Princesse Astrid', a boat orchid (family ORCHIDACEAE), actually a cross of 'Eagle' and 'Vesta', registered on January 1, 1932. After her marriage in 1926 to the Belgian Crown Prince Leopold, Princess Astrid enjoyed a lot of popularity in Belgium. When searching the internet we found a variety that unites their names: Rhododendron simsii 'Leopold Astrid'. This fancy-flowered variety of the Indian azalea has been hybridized and introduced by J. Haerens from Zomergem (Belgium) in 1933 (see ASA ${ }^{38}$ ).

Other Rhododendron cultivars are: 'Princesse Astrid', an evergreen azalea introduced by A. Steyaert 
in 1928, 'Leopold III' also an evergreen azalea introduced by A. Steyaert in 1934, and 'Mémoire Reine Astrid' again an evergreen azalea introduced by O. Franck \& Son in 1935 (see Leslie A.C. 2004).

Through Dendrologie online, we noticed a cultivar Rosa 'Koningin Astrid', registered in 1935.

Hibiscus syriacus 'Duc de Brabant' (a variety of rose mallow) is tricky because all Belgian crown princes bear this title. Since the variety name was introduced before 1872, the variety had been dedicated to King Leopold I or Leopold II.

\section{Zoological taxa}

Our searches revealed near 400 entries that had 'leopold' and near 100 entries that had 'astrid' in their taxon name. However, after scrutinization of these names, only 142 could be retained as eponymous to Leopold III and 26 to Astrid.

\section{Arthropods (phylum ARTHROPODA)}

Class Arachnida (arachnids): order Araneae (spiders)

Caponina leopoldi Zapfe, 1962. • TD: Holotype CNU in Museo del Centro de Investigaciones Zoologicas (now Museo Nacional de Historia Natural). • TL: Chili, Antofagasta Province, Taltal, Paposo.

Hahnia leopoldi Bosmans, 1982. • TD: Holotype RMCA 155206; 26 paratypes RMCA 15863-158635. • TL: Cameroon (now Republic of Cameroon), Mount Cameroon, montane forest, $1900 \mathrm{~m}$. $\bullet$ Remark: In the original description, 22 paratypes are mentioned, but 26 'paratypes' are present in the RMCA collection.

Jocquella leopoldi Baert, 1980. • TD: Holotype RBINS I.G.25681/EVCT.3600; 2 paratypes RBINS I.G.25681/ EVCT.3620-3621. • TL: Papua New Guinea, Madang Province, Yoro. • Remarks: These specimens were collected by one of us (JVG), current executive secretary to the KLFNEC. The generic name Jocquella is an eponym after Dr. Rudy Jocqué, former head of the zoology department at the RMCA and tutor of describer Dr. L. Baert of the RBINS. It was introduced as a new generic name in Baert (1980).

Nicodamus leopoldi Roewer, 1938. • TD: 2 syntypes RBINS I.G.9223/EVCT.3601-3602. • TL: Indonesia, Papua, Angi Gita Lake.

Plotius leopoldi Roewer, 1938. • TD: 3 syntypes RBINS I.G.9223/EVCT.3603-3605. • TL: Indonesia, Papua, Sakoemi, Aru-Inseln, Soengai Manoembaai.

Scytodes leopoldi Giltay, 1935. • TD: Holotype RBINS I.G.9796/EVCT.3607. • TL: (Malaysia), Malacca, Fraser's Hill. - Remark: This species has recently been redescribed, under the combination Stedocys leopoldi (Giltay, 1935), by Labarque et al. (2009).

Telamonia leopoldi Roewer, 1938. • TD: Holotype RBINS I.G.9223/EVCT.3606. • TL: Indonesia, Papua, Sakoemi.

Class ARACHNiDA (arachnids): order Astigmata (astigmata mites)

Murichirus (Murichirus) leopoldi Fain, 1974. - TD: Holotype RBINS I.G.24868/88a-59a; 10 paratypes RBINS I.G.24868/77-51a, 81b, 52a-b, 53a-b, 54a, 88a, 59b, 60a-b. • TL: Indonesia, Papua, Sentani. • Remarks: The expedition that uncovered this species was funded by the KLFNEC, and the species was named explicitly after Leopold III.

Teinocoptes astridae Fain, 1959. - TD: 6 syntypes RMCA 114735 and RBINS 2463-2466. • TL: Ruanda-Urundi (Republic of Rwanda), Astrida (now Butare); Ruanda-Urundi (Republic of Rwanda), Nyiakibanda. $\bullet$ Remarks: Fain (1959) stated that the holotype and one female (presumably a paratype) were deposited in the RMCA, and 4 female paratypes together with a nymph were deposited in his personal collection; the latter seem to have been transferred to the RBINS, but the whereabouts of the nymph is unknown. As the holotype is not identified in the RMCA collection, all these specimens should be considered syntypes. 
Class Arachnida (arachnids): order Mesostigmata (mesostigmata mites)

Astridiella Fain, 1957a. • TD: The type species of this genus, by monotypy, is Astridiella scotornis (Fain, 1956) (originally Ptilonyssus scotornis Fain, 1956), the holotype of which, from Muhero (Rwanda), is RMCA 112423. • Remarks: Fain (1957b) proposed to replace the original type specimen by a new one, RMCA 112422 from Akanyaru (Rwanda), because the original one was in bad condition. This nomenclatural act is invalid, as replacement of a name-bearing type by a neotype because the original type is a nomen dubium is permitted by Article 75.5 of the current version of the zoological Code only after the Commission has set it aside under its plenary power (Article 81). Fain (1957b) added two more species to Astridiella: A. caprimulyi Fain, 1957 and A. neotis Fain, 1957.

Neocypholaelaps leopoldi Elsen, 1972. • TD: Holotype RMCA 141866; 1 paratype RMCA 170358. • TL: Zaïre (now Democratic Republic of the Congo), Boma Kandi.

Ptilonyssus astridae Fain, 1956. - TD: Holotype RMCA 112456. • TL: Rwanda, Astrida (now Butare).

Rhinophaga leopoldi Fain, 1957c. • TD: Syntypes RMCA 99601-99602. • TL: Congo Belge (now Democratic Republic of the Congo), Kivu, Irangi. • Remarks: The original publication states that the name is based on 1 female and 1 male 'types', and on 2 female and 1 male 'paratypes'. In zoological nomenclature, the qualification of 'holotype' applies only for single specimen, so these 5 specimens must be considered syntypes. The database of the RMCA lists two 'holotypes'. The 'paratypes' could not be found.

Class ARACHNida (arachnids): order OpILIONES (harvestmen)

Gagrella Leopoldi Giltay, 1930. • TD: Holotype RBINS I.G.9223/EVCT.3608. • TL: Indonesia, Papua, between Lomira and Lake Kamakawalar. $\bullet$ Remark: According to Article 32.5.2.5 of the zoological Code, the specific epithet of this name should be corrected in leopoldi.

Paradampetrus Leopoldi Giltay, 1930. • TD: Holotype RBINS I.G.9223/EVCT.3609. • TL: Indonesia, Sumatra, Harau Kloof (now Harau Valley). - Remarks: [1] Paradampetrus leopoldi is the type species of Paradampetrus Giltay, 1930, by monotypy. [2] According to Article 32.5.2.5 of the zoological Code, the specific epithet of this name should be corrected in leopoldi.

Class Arachnida (arachnids): order Prostigmata (prostigmata mites)

Astrida Fain, 1955. - TD: The type species of this genus, by monotypy, is Astrida caprimulgi Fain, 1955, the holotype of which, from Astrida (now Butare, Rwanda), is RMCA 12407. • Remarks: Astrida is also the name given by the Belgian colonial rulers, in honor of Queen Astrid, to the city of Butare in southern Rwanda. The city held the so-called Laboratoire Médical d'Astrida.

Neastrida Fain, 1962 (subgenus). • TD: The type species of this subgenus, by monotypy, is Astrida parrae Fain, 1956, the holotype and 1 paratype of which, from Astrida (now Butare, Rwanda), are kept under the same number RMCA 112405 .

Class Arachnida (arachnids): order Pseudoscorpionida (false scorpions or book scorpions)

Apocheiridium leopoldi Vitali-di Castri, 1962. • TD: Holotype and 1paratype ('allotype') CNU in Museo Nacional de Historia Natural de Santiago de Chile (Museum Nacional d'Historia Natural). • TL: Chile, Cerro El Roble (32 $58^{\prime}$ S, $\left.71^{\circ} 02^{\prime} \mathrm{W}\right)$.

Class DiPlopoda (millipedes): order Polydesmida (flat-backed millipedes)

Platyrhacus principalis Attems, 1932. • TD: Syntypes supposed to be RBINS I.G.9223/CNU, not located at present. TL: Indonesia, Aroe Islands Manoembai. • Remarks: At first sight this is not an eponym after Leopold III, but given that Attems (1932) explicitly stated that it was Prince Leopold who found this species and given that 'principalis' is derived from the Latin word princeps, meaning the first or foremost (a term used for the emperor during the first centuries of the Roman Empire) and that the title Prince is derived from this word, leaves no doubt that this is indeed an eponym after Leopold III. 
Class InSECTA (insects): order BLATTODEA (cockroaches)

Macrocerca leopoldi Hanitsch, 1931. • TD: 2 syntypes RBINS I.G.9223/EVCT.2332. • TL: Indonesia, Papua, Angi Gita Lake.

Class InSECTA (insects): order COLEOPTERA (beetles)

Aegus leopoldi Didier, 1932. • TD: Holotype RBINS I.G.9223/EVCT.2972; 3 paratypes NHM 411067.1-3. • TL: Indonesia Papua, Angi Gita Lake.

Anartioschiza Leopoldi Burgeon, 1946. - TD: Most possibly RMCA CNU. • TL: Democratic Republic of the Congo, Bomokandi source; Aru; Mongbwalu. • Remark: According to Article 32.5.2.5 of the zoological Code, the specific epithet of this name should be corrected in leopoldi.

Apteromerus Leopoldi Gebien 1935. - TD: Holotype RBINS I.G.9223/EVCT.2273; 1 paratype RBINS I.G.9223/ EVCT.2467. • TL: Indonesia, Papua, Sakoemi. • Remark: According to Article 32.5.2.5 of the zoological Code, the specific epithet of this name should be corrected in leopoldi.

Arcastes astridae Laboissière, 1932. • TD: Holotype RBINS I.G.9223/EVCT.2355. • TL: Indonesia, Sumatra, TandjongSlamat.

Astridella Laboissière, 1932. - TD: The type species of this genus, by original designation, is Astridella guineensis Laboissière, 1932, the holotype of which, from Papua (Indonesia), is RBINS I.G.9223/EVCT.2658. • Remark: In a footnote, Laboissière (1932) described a second Astridella: A. cyanipennis.

Athemus Astridae Pic, 1933. • TD: Holotype RBINS I.G.9796/EVCT.2463. • TL: Malaysia, Malacca, Fraser's Hill. - Remarks: [1] According to Article 32.5.2.5 of the zoological Code, the specific epithet of this name should be corrected in astridae. [2] In the same publication, Dascillus leopoldi Pic, 1933 was also introduced, based on a single specimen.

Aulacophora leopoldi Laboissière, 1934. • TD: Holotype RBINS I.G.9796/EVCT.2465. • TL: Philippines, Samar, Mauo River.

Barombia Leopoldi Laboissière, 1929. • TD: Holotype RMCA CNU. • TL: Democratic Republic of the Congo, Lac Leopold II (now Lake Mai-Ndombe). • Remarks: [1] Laboissière (1931) proposed the nomen novum Barombiella Laboissière, 1931 for Barombia Jacoby, 1903, as it is preoccupied by Barombia Karsch 1891. [2] According to Article 32.5.2.5 of the zoological Code, the specific epithet of this name should be corrected in leopoldi.

Cassena leopoldi Laboissière, 1932. • TD: Holotype RBINS I.G.9223/EVCT.2360. • TL: Indonesia, Papua, Siwi.

Chlaenius (Chlaeniostenus) Leopoldi Burgeon, 1935. • TD: 3 syntypes in RMCA CNU. • TL: Democratic Republic of the Congo: Uele-Ituri, Bomokandi sources; Amadi; Niangara. • Remark: According to Article 32.5.2.5 of the zoological Code, the specific epithet of this name should be corrected in leopoldi.

Chrysodema leopoldiana Théry, 1933. • TD: Holotype RBINS I.G.9223/EVCT.3436. • TL: Philippines, Mauo Samar.

Chrysodema radians ssp. Leopoldi Théry, 1932. • TD: Holotype RBINS I.G.9223/EVCT.2167. • TL: Indonesia, Papua, Manoï. • Remark: According to Article 32.5.2.5 of the zoological Code, the specific epithet of this name should be corrected in leopoldi.

Cladophorus Leopoldi Pic, 1932b. • TD: Holotype RBINS I.G.9223/EVCT.2557. • TL: Indonesia, Papua, Lomira. • Remark: According to Article 32.5.2.5 of the zoological Code, the specific epithet of this name should be corrected in leopoldi.

Coccinella Leopoldi Mader in Sicard et al., 1933. • TD: Holotype RBINS I.G.9223/EVCT.2256; 1 paratype RBINS I.G.9223/EVCT.2256. • TL: Indonesia, Banda Island, Goenoeng Api. • Remarks: [1] Dr. Sicard died before finishing his work, so Mader and Arrow completed the publication. [2] According to Article 32.5.2.5 of the zoological Code, the specific epithet of this name should be corrected in leopoldi.

Coenochilus leopoldi Bourgoin 1931a. • TD: Holotype RBINS I.G.9223/EVCT.2326. • TL: Indonesia, Sumatra, Pageralam.

Coptorrhynchus leopoldi Marshall, 1935. • TD: Holotype RBINS I.G.9223/EVCT.2369; 1 paratype RBINS I.G.9223/ EVCT.2369. • TL: Indonesia, Celebes (now Sulawesi), Virgin forest between Paloe and Koelawi.

Cymophorus Leopoldi Bourgoin, 1929. • TD: Holotype possibly RMCA CNU. • TL: Congo belge (now Democratic Republic of the Congo), Inkisi. • Remark: According to Article 32.5.2.5 of the zoological Code, the specific epithet of this name should be corrected in leopoldi.

Damarsila umbrosa ssp. Leopoldi Théry, 1929. • TD: 2 syntypes, possibly RMCA CNU. • TL: Democratic Republic of the Congo, Bomokandi Sources. • Remark: According to Article 32.5.2.5 of the zoological Code, the specific epithet of this name should be corrected in leopoldi.

Daphysia leopoldi Fisher, 1934. • TD: Holotype USNM 57544; 4 paratypes C. F. Baker collection 22199, now USNM CNU; 1 paratype RBINS I.G.9796/ EVCT.3610. • TL: Republic of the Philippines, Samar, Mauo. • Remark: Pictures of holotype available on website of USNM.

Dascillus Leopoldi Pic, 1933. • TD: Holotype RBINS I.G.9796/EVCT.3455. • TL: Malaysia, Malacca, Fraser's Hill. 
- Remarks: [1] According to Article 32.5.2.5 of the zoological Code, the specific epithet of this name should be corrected in leopoldi. [2] In the same publication, Athemus astridae Pic, 1933 was also introduced.

Diaphanes latipennis var. Léopoldi Pic, 1931. • TD: Holotype RMCA CNU. • TL: Democratic Republic of the Congo, Barumbu. - Remark: According to Articles 32.5.2.1 and 32.5.2.5 of the zoological Code, the specific epithet of this name should be corrected in leopoldi.

Dorcus astridae Didier, 1932. • TD: Holotype RBINS I.G.9223/EVCT.2470. • TL: Indonesia, Célèbes (now Sulawesi), Menado, Tondano-Menado.

Gnatocera cruda Janson var. Leopoldi Bourgoin,1929. • TD: Holotype possibly RMCA CNU. • TL: Congo belge (now Democratic Republic of the Congo), Bomokandi source. • Remark: According to Article 32.5.2.5 of the zoological Code, the specific epithet of this name should be corrected in leopoldi.

Gynandrophthalma leopoldi Burgeon, 1942. • TD: Holotype RMCA CNU; 1 paratype possibly RBINS CNU. • TL: Democratic Republic of the Congo, Likimi, Bokapo (Kinshasa).

Heterorrhina Leopoldi Bourgoin, 1931b. - TD: Holotype possibly RMCA CNU. - TL: Democratic Republic of the Congo, Stanleyville (now Kisangani). • Remark: According to Article 32.5.2.5 of the zoological Code, the specific epithet of this name should be corrected in leopoldi.

Hister (s. str.) Leopoldi Desbordes, 1929. • TD: Holotype RMCA CNU. • TL: Democratic Republic of the Congo, Kivu. - Remark: According to Article 32.5.2.5 of the zoological Code, the specific epithet of this name should be corrected in leopoldi.

Lagria Leopoldi Pic, 1932a. • TD: Holotype RBINS I.G.9223/EVCT.3611. • TL: Indonesia, Papua, Manoi. • Remark: According to Article 32.5.2.5 of the zoological Code, the specific epithet of this name should be corrected in leopoldi.

Laius Leopoldi Pic, 1932b. • TD: Holotype RBINS I.G.9223/EVCT.2262; 14 paratypes RBINS I.G.9223/EVCT.2263. - TL: Indonesia, Misol, Weeim Island. • Remark: According to Article 32.5.2.5 of the zoological Code, the specific epithet of this name should be corrected in leopoldi.

Lesticus leopoldi Andrewes, 1932. • TD: Holotype RBINS I.G.9223/EVCT.2170. • TL: Indonesia, Aru Island, Soengai Manoembai.

Macrogyrus leopoldi Ball, 1932. • TD: Holotype RBINS I.G.9223/EVCT.2260; 2 paratypes RBINS I.G.9223/EVCT.2261.

- TL: Indonesia, Papua, Angi Gita Lake.

Macronota leopoldi Bourgoin, 1931a. • TD: Holotype RBINS I.G.9223/EVCT.2173. • TL: Indonesia, Sumatra, Fort de Kock (now Bukittinggi).

Mahutia Leopoldi Laboissière, 1929. • TD: Holotype RMCA CNU. • TL: Democratic Republic of the Congo, Kivu. • Remark: According to Article 32.5.2.5 of the zoological Code, the specific epithet of this name should be corrected in leopoldi.

Microserica leopoldiana Balthasar, 1932. • TD: 88 syntypes RBINS I.G.9223/EVCT.2265. • TL: Indonesia, Sumatra, Takengon.

Neodrana leopoldi Laboissière, 1932. • TD: Holotype RBINS I.G.9223/EVCT.2365. • TL: Indonesia, Papua, Lomira.

Neoserica principalis Balthasar, 1932. • TD: Holotype RBINS I.G.9223/EVCT.2267. • TL: Indonesia, Sumatra, near Panti. • Remark: At first sight this is not an eponym after Leopold III, but given that Balthasar (1932) explicitly stated that it was Prince Leopold who found this species and given that 'principalis' is derived from the Latin word princeps, meaning the first or foremost (a term used for the emperor during the first centuries of the Roman Empire) and that the title Prince is derived from this word, leaves no doubt that this is indeed an eponym after Leopold III.

Oides leopoldi Laboissière, 1932. • TD: Holotype RBINS I.G.9223/EVCT.2251. • TL: Indonesia, Papua, Moemi. • Remark: The RBINS collection holds the label 'lectotype', but no publication wherein this was established was found; hence we treat the single here recovered and described by Laboissière (1932) as the holotype.

Ptilodactyla Léopoldi Pic, 1952. • TD: Holotype RMCA CNU. • TL: Democratic Republic of the Congo, Kivu. • Remark: According to Articles 32.5.2.1 and 32.5.2.5 of the zoological Code, the specific epithet of this name should be corrected in leopoldi.

Silidius Astridae urundiensis Pic, 1955. • TD: Holotype RMCA CNU. • TL: Urundi (now Burundi), Nyamusumu, Usumbura. • Remarks: [1] We found the nomen Silidius astridae Pic, 1955 mentioned in the Index to Organism Names $(\mathrm{ION})^{40}$. However, a thorough search through the Zoological Record from which ION harvests its content revealed only the name $S$. astridae var urundiensis Pic, 1955 wich we found in Pic (1955: 159). We can therefore only conclude that "S. astridae" Pic, 1955 is a nomen nudum. [2] According to Article 45.6.4 of the zoological Code, S. astridae var. urundiensis Pic, 1955 is to be considered a subspecific name, as S. astridae urundiensis Pic, 1955.

Silidius Leopoldi Pic, 1929a. • TD: 2 syntypes most possibly in RMCA ENT000013260. • TL: Democratic Republic of the Congo, Kivu. - Remark: According to Article 32.5.2.5 of the zoological Code, the specific epithet of this name should be corrected in leopoldi.

Sphaeroderma leopoldi Maulik, 1935. • TD: Holotype RBINS I.G.9223/EVCT.2253. • TL: Indonesia, Sumatra, Singalang.

Spinanomala leopoldi Burgeon, 1932. • TD: Holotype RBINS I.G.9223/EVCT.3612. • TL: Indonesia, Sumatra, Harau Kloof. 
Stigmodera (Castiarina) astridae Deuquet, 1938. • TD: Holotype in collection of Deuquet; 1 paratype in NHM CNU; 1 paratype RBINS CNU. • TL: Australia, New South Wales, Illawarra Coastal Range.

Trichalus Leopoldi Pic, 1932b. • TD: Holotype RBINS I.G.9223/EVCT.2259. • TL: Indonesia, Aroe Islands, Manoembai.

Zonabris amplectans var. nov. Leopoldi Pic, 1929b. • TD: Holotype most possibly RMCA CNU. • TL: Democratic Republic of the Congo, Bomakandi (sources). $\bullet$ Remark: According to Article 32.5.2.5 of the zoological Code, the specific epithet of this name should be corrected in leopoldi.

\section{Unavailable names}

"Ctenistes leopoldi". • TD: RBINS I.G.9223/EVCT.3366. • TL: Indonesia, Bali, Singaradia. • Remarks: We failed to find this name published; hence we treat it as unavailable. The specimen holds a label with annotation i.l. which means in litteris; no correspondence could however be found.

"Pachyrrhynchus speciosus subsp. samarensis f. n. regi" Voss, 1934. • TD: Holotype RBINS I.G.9796/EVCT.3613; 1 paratype RBINS I.G.9794/EVCT.3614. • TL: Philippines, Mauo, Samar. • Remark: Nomen unavailable for being infrasubspecific (Article 45.5 of the zoological Code).

"Paederus leopoldi" Bernhauer. • TD: 2 specimens RBINS I.G.9796/EVCT.3615-3616. • TL: Philippines, Lampo Batang, Samar, Mauo River. - Remarks: The two specimens are pictured in their conservation box on VCB. We failed to find this name published; hence we treat it as unvailable.

"Silidius Astridae" Pic, 1955. • Remark: See above under Silidius Astridae urundiensis Pic, 1955.

Class InSECta (insects): order DiPTERA (flies)

Caricea leopoldi Curran, 1929. • TD: Holotype RMCA CNU; 2 paratypes RMCA CNU. • TL: Democratic Republic of the Congo, Burunga; Kivu.

Chrysosoma leopoldi Parent, 1932. • TD: Holotype RBINS I.G.9223/EVCT.2381. • TL: Indonesia, Papua, Sakoemi.

Cymatopus leopoldi Meuffels \& Grootaert 1984. • TD: Holotype RBINS I.G.26480/EVCT.3617; paratype RBINS I.G.26.480/EVCT.3618 with leg, abdomen and wing mounted on separate microscope slides. • TL: Papua New Guinea, Madang Province, Hansa Bay, Laing Island.

Euphumosia leopoldi Malloch, 1934. • TD: Holotype RBINS I.G.9223/EVCT.2377. • TL: Indonesia, Papua, Siwi Forest.

Mydaselpis leopoldi-tertii Bequaert, 1940. • TD: Holotype RBINS I.G.10483/CNU; 1 paratype RMCA CNU. • TL: Democratic Republic of the Congo, Eala. • Remark: According to Article 32.5.2.3 of the zoological Code, the specific epithet of this name should be corrected in leopolditertii.

Polypedilum leopoldi Goetghebuer, 1932. • TD: Holotype RBINS I.G.9223/EVCT.2380. • TL: Indonesia, Borneo, Samarinda.

Tipula (Formotipula) leopoldi Alexander, 1937. • TD: Holotype RBINS I.G.9796/EVCT.3619. • TL: Malaysia, Malacca, Frasir's Hill (Fraser's Hill, most probably).

Class InSECTA (insects): order HeMiPTERA (true bugs)

Acanthocoris Leopoldi Schouteden, 1929b. • TD: Holotype RMCA CNU. • TL: Democratic Republic of the Congo, Bas-Uélé (now Bas-Uele District). • Remark: According to Article 32.5.2.5 of the zoological Code, the specific epithet of this name should be corrected in leopoldi.

Agapophyta Astridae Schouteden, 1933. - TD: Holotype RBINS I.G.9223/EVCT.3409. • TL: Indonesia, Sumatra, Bireun. Remark: According to Article 32.5.2.5 of the zoological Code, the specific epithet of this name should be corrected in astridae.

Antilochus Astridae Schouteden, 1933. • TD: Holotype RBINS I.G.9223/EVCT.2460. • TL: Indonesia, Papua, Banda Island. - Remark: According to Article 32.5.2.5 of the zoological Code, the specific epithet of this name should be corrected in astridae.

Breddinia Leopoldi Schouteden, 1929c. • TD: Holotype RMCA CNU. • TL: Democratic Republic of the Congo, Kivu. - Remark: According to Article 32.5.2.5 of the zoological Code, the specific epithet of this name should be corrected in leopoldi.

Ceratopirates Leopoldi Schouteden, 1933. • TD: Holotype RBINS I.G.9223/EVCT.2425. • TL: Indonesia, Papua, between Lomira and Kamakahwalla. - Remark: According to Article 32.5.2.5 of the zoological Code, the specific epithet of this name should be corrected in leopoldi. 
Clovia leopoldi Lallemand, 1931. • TD: Holotype RBINS I.G.9223/EVCT.3622. • TL: Indonesia, Java, Poedjon.

Conorhinus Leopoldi Schouteden, 1933. - TD: 1 syntype RBINS I.G.9223/EVCT.2426; 1 syntype CNU in Musée d'Amsterdam (collection now in Naturalis, Leiden). • TL: Indonesia, Papua, Sakoemi \& Wemdessi. • Remark: According to Article 32.5.2.5 of the zoological Code, the specific epithet of this name should be corrected in leopoldi.

Convarcia leopoldi Lallemand, 1931. • TD: Holotype RBINS I.G.9223/EVCT.2422. • TL: Indonesia, Papua, between Lomira and Lake Kamakahwalla.

Geocoris Leopoldi Schouteden, 1933. • TD: Holotype RBINS I.G.9223/EVCT.2144. • TL: Indonesia, Papua, Siwi. • Remark: According to Article 32.5.2.5 of the zoological Code, the specific epithet of this name should be corrected in leopoldi.

Halyomorpha Leopoldi Schouteden, 1933. • TD: 3 syntypes RBINS I.G.9223/EVCT.2429. • TL: Indonesia, Borneo; Tchgaoreng and Gohakama (East of Samarinda). • Remark: According to Article 32.5.2.5 of the zoological Code, the specific epithet of this name should be corrected in leopoldi.

Hemisphaerius astridae Lallemand, 1931. - TD: Holotype RBINS I.G.9223/CNU; 1 paratype RBINS I.G. 9223/CNU. • TL: Indonesia, Celebes (now Sulawesi), between Paloe and Koelawi.

Laccophorella Leopoldi Schouteden, 1929c. • TD: Holotype RMCA CNU. • TL: Democratic Republic of the Congo, Kissenyi. - Remark: According to Article 32.5.2.5 of the zoological Code, the specific epithet of this name should be corrected in leopoldi.

Oncocephalus Astridae Schouteden, 1929c. - TD: Holotype RMCA CNU. • TL: Democratic Republic of the Congo, Kasai, Ilebo. • Remark: According to Article 32.5.2.5 of the zoological Code, the specific epithet of this name should be corrected in astridae.

Oncocephalus Leopoldi Schouteden, 1929c. • TD: Holotype RMCA CNU. • TL: Democratic Republic of the Congo, Bomakandi. • Remark: According to Article 32.5.2.5 of the zoological Code, the specific epithet of this name should be corrected in leopoldi.

Class INSECTA (insects): order HomopteRA (plant-feeding bugs)

Cryptotympana leopoldi Lallemand, 1931. • TD: Holotype RBINS I.G.9223/EVCT.3404. • TL: Indonesia, Sumatra, Bireun.

Patara leopoldi Van Stalle, 1982. • TD: Holotype RBINS I.G.26638/EVCT.3623. • TL: Republic of Cameroon, Mount Cameroon, vhf-track $1400 \mathrm{~m}$.

Class InSECTA (insects): order HyMENOPTERA (comprising ants, bees, wasps and sawflies)

Anthophora leopoldi Cockerell, 1933. - TD: Holotype RMCA CNU. • TL: Democratic Republic of the Congo, Kivu.

Chrysis (Trichrysis) singalensis Leopoldi Invrea, 1934. • TD: Holotype RBINS I.G.9223/EVCT.2448. • TL: Indonesia, Celebes (now Sulawesi), between Paloe and Koelaw. - Remark: According to Article 32.5.2.5 of the zoological Code, the specific epithet of this name should be corrected in leopoldi.

Anacharoides astrida Quinlan, 1979. • TD: Holotype RMCA CNU; 5 paratypes RMCA CNU. • TL: Republic of Rwanda, Astrida (now Butare or Huye); localities of paratypes available in Quinlan (1979). • Remark: This is a secondary eponym, named after the city Astrida, itself named after Princess Astrid.

Polyrhachis (Chariomyrma) leopoldi Santschi, 1932. • TD: Holotype RBINS I.G.9223/EVCT.2435; 2 paratypes RBINS I.G.9223/EVCT.2434. • TL: Indonesia, Moluccas, Ternate Island.

Pseudolasius leopoldi Santschi, 1932. • TD: Holotype RBINS I.G.9223/EVCT.2445; 40 paratypes RBINS I.G.9223/ EVCT.2446 (1 specimen only). • TL: Indonesia, Borneo, East of Samarinda, Mahakam mouth.

Mesostenoideus leopoldi Cheesman, 1932. • TD: Holotype RBINS I.G.9223/EVCT.3624; 2 paratypes MNH CNU. • TL: Indonesia, Papua, Siwi, Momi Waren.

Megameris (Penimeris) leopoldi Betrem \& Bradley, 1972. • TD: Holotype RMCA CNU. • TL: Democratic Republic of the Congo, Kivu. • Remarks: Betrem \& Bradley (1972) did not describe this species, but simply stated that it had two subspecies: M. (P.) leopoldi leopoldi Betrem \& Bradley and M. (P.) leopoldi cameroonensis Betrem. We follow Article 46.1 of the zoological Code which states that "A name established for a taxon at either rank in the species group is deemed to have been simultaneously established by the same author for a taxon at the other rank in the group; both nominal taxa have the same name-bearing type, whether that type was fixed originally or subsequently". Therefore, we take M. (P.) leopoldi leopoldi Betrem \& Bradley, 1972 as providing availability to the epithet leopoldi. As for M. (P.) leopoldi cameroonensis, it was described in the same work by Betrem alone (in Betrem \& Bradley, 1972).

Megameris (Penimeris) leopoldi leopoldi Betrem \& Bradley, 1972. • TD: Holotype RMCA CNU. • TL: Democratic Republic of the Congo, Kivu. $\bullet$ Remark: In the same paper, a second subspecies of Megameris (Pennimeris) leopoldi was also described: M. (P.) leopoldi cameroonensis Bertem, 1972. 
Polistes tenebricosus var. leopoldi Bequaert, 1934. • TD: Holotype RBINS I.G.9796 CNU; 1 paratype MCZ CNU. • TL: Republic of the Philippines or Philippines, Negros. • Remark: The online collection database of the MCZ, accessed on 25.10.2016, does not list this taxon.

Ropalidia leopoldi Bequaert, 1932. • TD: Holotype RBINS I.G.9223/EVCT.2449); 38 paratypes RBINS I.G.9223/ EVCT.2450 (1 specimen only); 5 paratypes MCZ CNU. • TL: Indonesia, Papua, Angi Gita Lake. • Remark: The online collection database of the MCZ, accessed on 25.10.2016, does not list this species.

Class INSECTA (insects): order ISOPTERA (termites)

Schedorhinotermes longirostris var. Leopoldi Kemner, 1933. • TD: Holotype RBINS I.G.9223/EVCT.3422). • TL: Indonesia, Sumatra, Bireun.

Class INSECTA (insects): order LEPIDOPTERA (butterflies)

Astridia Kiriakoff, 1948. • TD: The type species of this genus, by original designation, is Sphecosoma angustata Möschler, 1878 , the 2 syntypes of which, from the Republic of Suriname, are possibly in the Museum of Natural History, Berlin CNU. - Remark: Astridia is a junior objective synonym of Pleurosoma Orfila, 1935 according to Watson et al. (1980).

Bradina Leopoldi-III Ghesquière, 1942. • TD: Holotype RMCA CNU. • TL: Democratic Republic of the Congo, Kivu, Kissenyi. • Remark: According to Article 32.5.2.4.2 of the zoological Code, the specific epithet of this name should be corrected in leopoldi.

Bunaea Leopoldi Bouvier, 1930. • TD: Holotype RMCA CNU. • TL: Democratic Republic of the Congo, Stanleyville (now Kisangani). - Remarks: [1] According to Article 32.5.2.5 of the zoological Code, the specific epithet of this name should be corrected in leopoldi. [2] Bouvier (1930) also dedicated two new species to the mother of Prince Leopold, based on material collected by Queen Elisabeth of Belgium: Micragone Elisabethae and Bunaea Reginae.

Careades hemichlora leopoldina Roepke, 1932. • TD: Holotype RBINS I.G.9223/HET VPL (1929). • TL: Indonesia, Sulawesi, Tonsea Lama.

Charaxes smaragdalis f. reg. Leopoldi Ghesquière, 1933. - TD: Holotype and 1 paratype RMCA CNU; 1 paratype RBINS I.G. 9223/PAP GEN. • TL: Democratic Republic of the Congo, Komi (Lodja Territory), La Kondue (border of the Sankuru). • Remark: According to Article 32.5.2.4.2 of the zoological Code, the specific epithet of this name should be corrected in leopoldi.

Coptobasoides léopoldi Janse, 1935. • TD: Holotype I.G.9223/HET VPL (1929); 2 paratypes RBINS I.G.9223/HET VPL (1929). • TL: Indonesia, Celebes (now Sulawesi), Menado, Tonsea Lama. • Remark: According to Article 32.5.2.1 of the zoological Code, the specific epithet of this name should be corrected in leopoldi.

Cymothoe excelsa ssp. Regis-Leopoldi Overlaet, 1944. • TD: Holotype RMCA CNU; 1 paratype RMCA CNU. • TL: Democratic Republic of the Congo, Stanleyville (now Kisangani). • Remark: According to Article 32.5.2.2 of the zoological Code, the subspecific epithet of this name should be corrected in regisleopoldi.

Diacrisia leopoldi Tams, 1935. • TD: Holotype I.G.9223/PAP VRL (1929); 2 paratypes RBINS I.G.9223/PAP VRL (1929). • TL: Indonesia, Celebes (now Sulawesi), Menado, Tondano-Menado, Tonsea Lama.

Eilema leopoldi Tams, 1935. • TD: Holotype RBINS I.G.9223/PAP VRL (1929). • TL: Indonesia, Java, Pendjaloe.

Gastropacha pardale leopoldi Tams, 1935. • TD: Holotype RBINS I.G.9223/HET VPL (1929). • TL: Indonesia, Borneo, Balikpapan.

Lechriolepis leopoldi Hering, 1929. • TD: Holotype RMCA CNU. • TL: Democratic Republic of the Congo, Lukolela.

Leopoldina Hering, 1934. • TD: The type species of this genus, by monotypy, is Leopoldina leopoldi Hering, 1934 (see below).

Leopoldina leopoldi Hering, 1934. • TD: Holotype RBINS I.G.9796/HET VPL (1932). • TL: Siam (now Thailand), Prae.

Nyctemera leopoldi Tams, 1935. • TD: Holotype RBINS I.G.9223/PAP VRL (1929). • TL: Indonesia, Papua, Sakoemi.

Odonestis vita leopoldi Tams, 1935. • TD: Holotype RBINS I.G.9776/HET VPL (1932); 3 paratypes NHM CNU. • TL: Philippines, Mauo-Samar.

Spilosoma leopoldi Debauche, 1942. • TD: 2 syntypes RBINS I.G.14919/HET GEN. • TL: Democratic Republic of the Congo, Parc National Albert (now Virunga National Park), Magera Lake; Kivu, Burunga (W. Kamatembe).

Syntomis leopoldi Hering, 1934. • TD: Holotype RBINS I.G.9796/PAP VRL (1929); 1 paratype RBINS I.G.9796/HET VPL (1932). • TL: Siam (now Thailand), Prae, Mekami. • Remark: Senior primary homonym of Syntomis leopoldi Tams, 1935; the problem of homonymy has, thanks to the efforts preparing the present paper, recently been resolved (De Freina \& De Prins 2018), whereby S. leopoldi Hering, 1934 was transferred to Amata as Amata leopoldi (Hering, 1934) comb. n.. 
Syntomis leopoldi Tams, 1935. • TD: Holotype RBINS I.G.9223/PAP VRL (1929). • TL: Indonesia, Celebes (now Sulawesi), Menado, Tondano-Menado, Tonsea Lama. - Remark: Junior primary homonym of Syntomis leopoldi Hering, 1934; the problem of homonymy has recently been resolved (De Freina \& De Prins 2018) whereby S. leopoldi Tams, 1935 was renamed as Amata tamsi mom. n..

Trabala leopoldi Tams, 1935. • TD: Holotype RBINS I.G.9796/HET VPL (1932). • TL: Indonesia, Celebes (now Sulawesi), Makassar.

Xanthorhoë leopoldi Debauche, 1938. • TD: Holotype and 3 paratypes (including one 'allotype') RMCACNU; 2 paratypes RBINS I.G.14501/HET GEN). • TL: Democratic Republic of the Congo, Parc National Albert (now Virunga National Park), Bishakishaki river, Kamatembe. $\bullet$ Remark: According to Article 27 and 32.5.2.1 of the zoological Code, the generic name should be corrected in Xanthorhoe.

\section{Unavailable names}

"Philosamia Cynthia Dry., f. canningi Hutt. ssp. Leopoldi" Le Cerf, 1933. • TD: Holotype RBINS I.G.9796/HET VPL (1932). • TL: Indonesia, Java, Nongkodjadar. • Remark: Nomen unavailable for being infrasubspecific (Article 45.5 of the zoological Code).

"Vanessa io ab. Astrida" Derenne, 1926 (Fig. 1). • TD: Holotype RBINS I.G.13655/PAP BEL). • TL: Brussels, Boisfort (Sonian Forest). • Remark: Nomen unavailable for being infrasubspecific (Article 45.6.2 of the zoological Code).

Class InSECTA (insects): order Mantodea (mantises)

Parhierodula leopoldi Werner, 1931. • TD: Holotype RBINS I.G.9223/EVCT.3625; 1 paratype RBINS I.G.9223/ EVCT.3626. • TL: Indonesia, Aru Islands, Manoembai. • Remark: This species was recently re-described in depth by Vermeersch \& Vansembrouck (2019).

Class InSECTA (insects): order NeUROPTERA (net-winged insects)

Climaciella Leopoldi Lestage, 1934. - TD: Holotype RBINS I.G.9796/EVCT.3627. • TL: Vietnam, Tonkin (now Vietnam), Phu-Ho. • Remark: According to Article 32.5.2.5 of the zoological Code, the specific epithet of this name should be corrected in leopoldi.

Necyla leopoldi Navas, 1931. • TD: Holotype RBINS I.G.9223/EVCT.2471. • TL: Indonesia, Papua, Lomira.

Class InSECTA (insects): order ODONATA (dragonflies and damselflies)

Neurobasis leopoldi Fraser, 1932. • TD: Holotype RBINS I.G.9223/EVCT.2352. • TL: Indonesia, Papua, Waideri River.

Procordulia astridae Lieftinck, 1935. - TD: 2 types, whereabouts unknown. • TL: Indonesia, Papua, Cycloop Mts.

Procordulia leopoldi Fraser, 1932. • TD: Holotype RBINS I.G.9223/EVCT.2351. • TL: Indonesia, Papua, Angi Gita Lake.

\section{Unavailable name}

"Phyllogomphus leopoldi" Fraser. • TD: Holotype RBINS I.G. CNU/CNU. • TL: Democratic Republic of the Congo, Kinshasa. • Remark: We failed to find correspondence on this species. We follow Dijkstra et al. (2006) who regarded this name as unavailable.

Class INSECTA (insects): order ORTHOPTERA (comprising grasshoppers, locusts and crickets)

Acrida Leopoldi Sjöstedt, 1934. • TD: Holotype RBINS I.G.CNU/ORTH GEN 583521). • TL: Congo belge (Democratic Republic of the Congo), Plaine du Parc National Albert (now Plain of Virunga National Park). • Remark: According to Article 32.5.2.5 of the zoological Code, the specific epithet of this name should be corrected in leopoldi. 

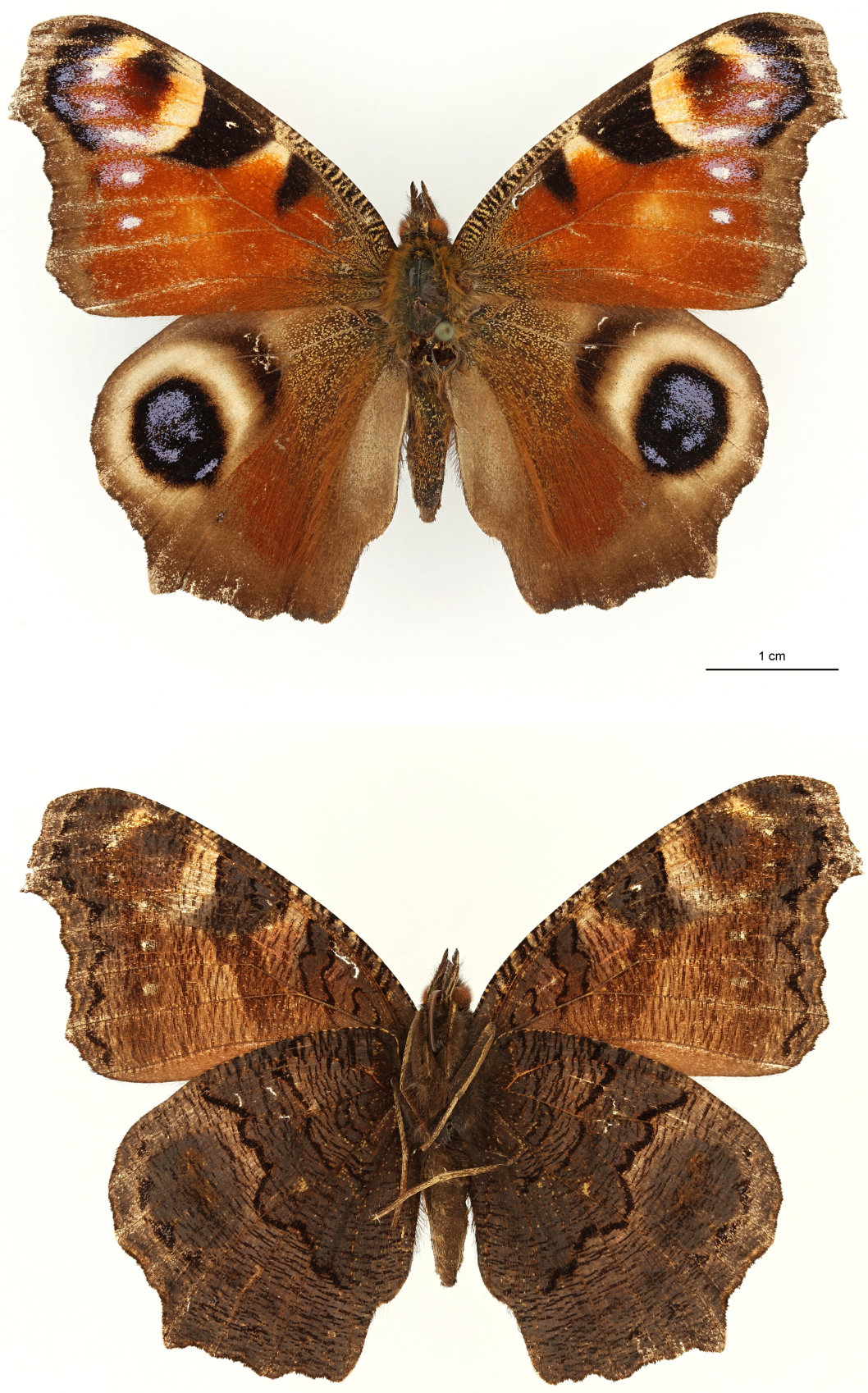

$1 \mathrm{~cm}$

FIGURE 1. Dorsal (top) and ventral (bottom) view of the aberrant peacock butterfly Vanessa io ab. astrida Derenne, 1926. The aberration is visible as yellowish oval markings on the ventral side of the anterior wings. It is the sole Belgian taxon described after the searched for royals (Pictures by C. Locatelli, copied from VCB; Copyright: RBINS / DIGIT-4 Belspo Licence: CC BY NC ND).

Kivuia Leopoldi Sjöstedt, 1929. - TD: 2 syntypes ('cotypes') Naturhistoriska riksmuseet (now Swedish Museum of Natural History) NRM-ORTH0003736-0003737. • TL: Democratic Republic of the Congo, Bas-Uélé (now Bas-Uele District). • Remark: According to Article 32.5.2.5 of the zoological Code, the specific epithet of this name should be corrected in leopoldi.

Lebinthus Leopoldi Chopard, 1931. • TD: 12 syntypes RBINS I.G.9223/EVCT.3628. • TL: Indonesia, Papua, Manoi, Arfak. • Remarks: [1] Material could not be located in the RBINS collection at time of investigation, possibly under external study. [2] According to Article 32.5.2.5 of the zoological Code, the specific epithet of this name should be corrected in leopoldi. 
Pseudonicsara Leopoldi Willemse, 1933. • TD: Holotype RBINS I.G.9223/EVCT.2393. • TL: Indonesia, Papua, Sakoemi. • Remark: According to Article 32.5.2.5 of the zoological Code, the specific epithet of this name should be corrected in leopoldi.

Class Insecta (insects): order Phasmatodea (stick insects and leaf insects)

Calvisia leopoldi Werner, 1934. • TD: Holotype RBINS I.G.9776/EVCT.2458. • TL: Indonesia, Bali, Tjandikoesoema. Palophus Leopoldi Schouteden, 1916. • TD: Holotype RMCA CNU. • TL: Democratic Republic of the Congo, Elisabethville (now Lubumbashi). • Remark: According to Article 32.5.2.5 of the zoological Code, the specific epithet of this name should be corrected in leopoldi.

Class Insecta (insects): order Plecoptera (stoneflies)

Neoperla leopoldina Navas, 1932. • TD: Holotype RMCA CNU. • TL: Democratic Republic of the Congo, Bomokandi (sources).

Class InSECTA (insects): order TrichOPTERA (caddisflies)

Chimarra leopoldi Jacquemart, 1981. • TD: Holotype RBINS I.G.24802/EVCT.3629; 1 paratype RBINS I.G.24802/ EVCT.3630. • TL: Indonesia, Irian Jaya (now Papua), Enarotali.

Class Malacostraca (malacostracans): order DECAPODA (ten-footed crustaceans)

Parapilumnus leopoldi Gordon, 1934. • TD: Holotype RBINS I.G.9223/INV.113700. • TL: Indonesia, Maluku Province, Banda Neira.

Class Malacostraca (malacostracans): order Isopoda (woodlice)

Parioninella astridae Nierstrasz \& Brender à Brandis, 1930. • TD: Holotype RBINS I.G.9223/INV.101863. • TL: Indonesia, Aru Islands.

Tachaea leopoldi Nierstrasz, 1930. • TD: Holotype RBINS I.G.9223/INV.112283. • TL: Indonesia, Aru Islands, Poelo Babi.

Class Maxillopoda (maxillopodans): order KentrogonidA

Sacculina leopoldi Boschma, 1931. • TD: Holotype RBINS I.G.9223/INV.101705. • TL: Indonesia, between Banda Neira and Goenoeng Api.

Class Ostracoda (seed shrimps): order Podocopida

Cythereis reginae-Astrid Van Veen, 1936. • TD: whereabouts types unknown. • TL: Ubaghs, Valkenburg, Kunrade. Remark: According to Article 32.5.2.3 of the zoological Code, the specific epithet of this name should be corrected in reginaeastrid.

\section{Cnidarians (phylum CNIDARIA)}

Class Anthozoa (anthozoans): order SCLERACTINIA (stony corals) 
Seriatopora leopoldi Thiel, 1932. • TD: Holotype RBINS I.G.9223/CNU. • TL: Indonesia, Papua, Sorong.

Porites astridae Thiel, 1932. • TD: Holotype RBINS I.G.9223/CNU. • TL: Indonesia, Papua, Mansfield Island.

Class Hydrozoa (hydrozoans): order AnTHoathecata (athecate hydroids)

Cnidocodon leopoldi Bouillon, 1978. • TD: 2 syntypes RBINS I.G.2573/INV.38923-38924; 1 syntype RBINS I.G.27838/ INV.38916. - TL: Papua New Guinea, Bismarck Sea, Hansa Bay and channel between Kairiru Islands and Mushu (Wewak). • Remark: This is the type species of Cnidocodon Bouillon, 1978, by original designation.

Class HydrozoA (hydrozoans): order LEPTOTHeCATA (thecate hydroids)

Thecocarpus leopoldi Leloup, 1930. • TD: Holotype RBINS I.G.9223/INV.40461). • TL: Indonesia, Papua, SorongDom.

\section{Echinoderms (phylum ECHINODERMATA)}

Class Asteroidea (starfish or sea stars): order VAlvatida (an order of starfish)

Culcita novae-guineae var. nov. leopoldi Engel, 1930. • TD: Holotype RBINS I.G.9223/AST.578. • TL: Indonesia, Mansfield Island. - Remark: According to Article 32.5.2.3 of the zoological Code, the specific epithet of this name should be corrected in novaeguineae.

Ophidiaster astridae Engel, 1930. • TD: Holotype RBINS I.G.9223/AST.918). • TL: Indonesia, Enoe Island.

\section{Molluscs (phylum MoLLUSCA)}

Class GASTROPODA (snails and slugs): order BASOMmatophora (air-breathing freshwater snails)

Ameria leopoldi Dupuis, 1931. • TD: 1 syntype RBINS I.G.9223/MT.2541. • TL: Indonesia, Arfak, Angi Gita Lake.

Class Gastropoda (snails and slugs): order CyCLONERITIDA (nerites and false limpets)

Aphanoconia leopoldi Benthem Jutting, 1958. • TD: Holotype RBINS I.G.9223/MT.2175); 1 paratype RBINS I.G.9223/ MT. 2006. • TL: Indonesia, Misool Island, Lilinta Forest.

Class Gastropoda (snails and slugs): order STYLOMmatophora (air-breathing land snails)

Papuina astridae Dupuis, 1931. • TD: Holotype RBINS I.G.9223/MT.2838. • TL: Indonesia, Manokwari.

Class GaStropoda (snails and slugs): order SySTELlommatophora (comprising primitive air-breathing slugs)

Oncidium Astridae Labbé, 1934. • TD: Holotype RBINS I.G.9223/MT.3822. • TL: Indonesia, Papua, Sorong. • Remark: According to Article 32.5.2.5 of the zoological Code, the specific epithet of this name should be corrected in astridae.

Oncidium Leopoldi Labbé, 1934. • TD: 3 syntypes RBINS I.G.9223/MT.3824. • TL: Indonesia, Pisang Island. Remark: According to Article 32.5.2.5 of the zoological Code, the specific epithet of this name should be corrected in leopoldi. 
Class Polyplacophora (chitons or sea cradles): order Chitonida (an order of chitons or sea cradles)

Acanthochites leopoldi Leloup, 1933. • TD: Holotype RBINS I.G.9223/MT.3805; 13 preparations RBINS I.G.9223/ MT.2957 and MT.3806. • TL: Indonesia, Manfield Island. • Remark: This species was recently redescribed by Sirenko \& Tai (2020).

Ischnochiton adelaidensis var. leopoldi Leloup, 1933. • TD: Holotype RBINS I.G.9796; MT.3621. • TL: Philippines, Asia Negros Island, South Coast.

\section{Ringed worms (phylum ANNELIDA)}

Class Clitellata (clitellates): order Haplotaxida (haplotaxids)

Pheretima (Pheretima) leopoldi Michaelsen, 1930. • TD: Holotype RBINS I.G.9223/CNU. • TL: Indonesia, Sumatra, Tandjong, Pageralam.

Pheretima principalis Michaelsen, 1932. • TD: Holotype RBINS I.G.9776/CNU. • TL: Indonesia, Bali, TsjandiKoesoema. • Remark: At first sight this is not an eponym after Prince Leopold III, but given that in his introduction Michaelsen (1932) explicitly refers to the fact that Prince Leopold sampled this species in June 1932 and given that the word 'principalis' is derived from the Latin word princeps, meaning the first or foremost (a term used for the emperor during the first centuries of the Roman Empire) and that the title Prince is derived from this, leaves no doubt that this is indeed an eponym after Leopold III.

\section{Roundworms (phylum NEMATODA)}

Class SECERNENTEA (secernenteans): order SPIRURIDA (spirurian roundworms)

Microfilaria leopoldi van den Berghe et al., 1957. • TD: Whereabouts of syntypes unknown. • TL: Unknown. • Remark: Even though we could not find the types, we chose to treat this name as an eponym to Leopold III given the date of publication, given that the host of this parasite was a gorilla from the Belgian Congo and that it was published in the magazine Institut pour la Recherche scientifique en Afrique centrale, institute in which several RBINS and RMCA scientists were on the scientific board.

\section{Velvet worms (phylum ONYCHOPHORA)}

Class UdEONYCHOPHORA: order EUONYCHOPHORA (representing all living velvet worms)

Paraperipatus leopoldi Leloup, 1931. • TD: Holotype RBINS I.G.9223/INV.131201. • TL: Indonesia, Angi Gita Lake, Sakoemi. • Remarks: In their worldwide review of onychophoran taxonomy, Sena Oliveira et al. (2012) stated that $P$. leopoldi is best treated as a nomen dubium whereby they disagreed with Brongersma (1932) and Ruhberg (1985) who treated $P$. leopoldi as a junior synonym of P. papuensis (Sedgwick, 1910). The here recovered holotype of $P$. leopold $i$ will allow new taxonomic study that will allow to settle the taxonomic status of this name, if coupled to additional collecting efforts at the type locality (Sena Oliveira, pers. comm).

\section{Vertebrates (Phylum CHORDATA)}

Class ACtinopterygiI (ray-finned fishes): order CHARACIFORMEs (characids or characins)

Astyanax leopoldi Gery, Planquette \& Le Bail, 1988. - TD: Holotype RBINS I.G.24276/731; 45 paratypes RBINS I.G.24276 and I.G. 23074/732-737; 28 paratypes MNHN 1981.367-368, 1981.389, 1981.392, 1981.552, 1981.560, 191.565, 1981.568-569; 25 paratypes MHNG 2393.98, 2383.389. • TL: French Guiana, Saut Alicoto, Camopi, Moyen Oyapok. 
Class ACtinopterygiI (ray-finned fishes): order Cichliformes (cichlids and convict blennies)

Plataxoides leopoldi Gosse, 1963. • TD: Holotype RBINS I.G.23074/459; 26 paratypes RBINS I.G.23074/460. • TL: Brazil, Manacapuru, Solimoes river, Furo Cuai / Furo du village de Cuia (rive gauche du Solimöes en amont de Manacapuru).

Class ACTINOPTERYGII (ray-finned fishes): order MYCTOPHIFORMES (lanternfishes and blackchins)

Diaphus Astridae Giltay, 1929. • TD: Holotype RBINS I.G.2548/9223. • TL: Indonesia, Papua, Manokwari.

Class Actinopterygi (ray-finned fishes): order Perciformes (perch-like fishes)

Synchiropus leopoldi Giltay, 1933. • TD: Holotype RBINS I.G.9223/40. • TL: Indonesia, between Banda Neira and Goenoeng.

Class Aмpнibia (amphibians): order ANURA (frogs and toads)

Asterophrys leopoldi de Witte, 1929. • TD: Holotype RBINS I.G.9223/1018. • TL: Indonesia, Papua, Vogelkop Peninsula, Arfak Mountains.

Class Chondrichthyes (cartilaginous fishes): order Myliobatiformes (batoids)

Potamotrygon leopoldi Castex \& Castello, 1970. • TD: Holotype RBINS I.G.23936/475. • TL: Brazil, Mato Grosso State, Auaia-Missu river, Alto Xingu (little creek on the right shore of Alto Xingu, down river of the Auaia-Missu, confluence).

Class RePtiLia (reptiles): order SQUamata (scaled reptiles)

Melanocalamus leopoldi de Witte, 1941. • TD: Holotype RMCA CNU. • TL: Ruanda (now Republic of Rwanda), Rwankeri.

Gehyra Leopoldi Brongersma, 1930. • TD: Holotype RBINS I.G.9223/2028). • TL: Indonesia, Manoi, Sorong.

\section{Discussion}

As shown in the list above, several taxonomists expressed their appreciation for the explorative work of Astrid and Leopold III, and this even post mortem (Astrid died in a car accident in 1935 and Leopold passed away in 1983) by dedicating new taxa to Astrid and Leopold III. The second wife of King Leopold III, Princess Lilian of Belgium, Princess of Réthy, born Lilian Baels, did not participate in expeditions led by King Leopold III which could explain why we could not find any eponyms such as lilianae, baelsae or rethyensis.

Samyn et al. (2016) already provided an overview of the temporal (year of eponymy) and geographical distribution of the authors that attributed the concerned eponyms. In that same publication, these authors also provided an overview per taxon. Their conclusions can here be recaptured as follows: [1] the majority of eponymous taxa were gathered by the royals in central Africa, South-East Asia and South America (cf. table 1 below and the website of the KLFNEC that lists the expeditions of Leopold III in chronological order ${ }^{41}$ ); [2] most of the eponyms were given by Europeans (mainly 
Belgians, but also French, British, Germans and Italians); [3] the bulk of the eponyms are insects and spiders $(>80 \%)$ with molluscs $(4 \%)$ and fish $(3 \%)$ following and with several other phyla represented by smaller percentages/singletons.

No suprageneric taxa have been attributed to Leopold III and/or Astrid. This comes as no surprise as these two persons were not biologists, let alone taxonomists. Their numerous expeditions were certainly fruitful in the acquisition of natural history collections of mainly zoological nature, but they are to be seen as a reflection of an epoch wherein the monarchy rimed international diplomacy with scientific and cultural explorations.

The RBINS proved a preferred place for Leopold III to review and study part of his collections, in particular shells and corals. He paid many visits to the RBINS collection rooms especially in the 1970's. From discussions with the then RBINS director, Prof. André Capart, the idea to establish a Fund aiming to promote nature exploration and conservation took shape. This Fund, the King Leopold III Fund for Nature Exploration and Conservation, was formerly established on 8 June 1972. It continues to exist today and is now under the Presidency of Princess Esmeralda of Belgium. The scientific archive of Leopold III, comprising an impressive iconography, a library and above all most of his gathered collections, is curated at the RBINS. African collections, on the other hand, are mainly curated at the RMCA.

It is quite likely that we still have missed a few eponyms named after Leopold III and Astrid. It can for instance be that not the name, but the function was used in an eponymous scientific name. For instance, in 1929 Bourgoin described Cymophorus leopoldi, but also Coenochilus regalis, based on material collected by Prince Leopold in 1925 in Congo belge (now Democratic Republic of the Congo). Although it is not explicitly put by Bourgoin (1929), it is very probable that C. regalis is also an eponym for Leopold III. But as this could be deduced neither from the collection labels nor from the publication, we omitted it. Archives, such as correspondence between taxonomists/directors and Leopold III/his administration, would need to be consulted to ascertain such assumptions. We did not walk this line of research.

On the other hand, our conservative approach to not too lightly accept potential eponyms as being adjusted to the correct royalties can be illustrated by two Congolese chironomid species described by Goetghebuer (1936): Chironomus (Carteria) regalis and Chironomus (Chironomus) reginae. Both appeared to be named after Queen Elizabeth of Belgium, the mother of Leopold III. Same was true for a lot of 'leopold' eponyms that were named after Leopold I or II of Belgium.

Taxonomists, be they botanists, phycologists, zoologists or other, have been using eponyms for a long time to honour and praise leading scientists (e.g., after Darwin: Milicic et al., 2011) or personalities (e.g., the Cuban 'Obama bee' Lassioglossum obamai Genaro, 2016). Non taxonomists such as cultivar breeders on the other hand use eponymous names to draw attention to their new breed. In the latter case, the main focus does not seem to be with scientific recognition, but with publicity and commercialization.

We recall that the cultivar is the basic grouping, named culton (taxon), for cultivated varieties. The word 'cultivar' was coined by Bailey in 1923 and is now commonly used. The naming of cultivars is governed by the International Code of Nomenclature for Cultivated Plants (ICNCP), also known as the 'Cultivated Plant Code'. This is a system separate from that used for wild plants, the International Code of Botanical Nomenclature (ICN).

A cultivar name can only be given to cultivated plants whose origin or selection is primarily due to the intentional actions of breeders. The name of the variety is put between single quotes after the scientific species name. The equivalent of an ICN holotype is the standard. This usually includes an herbarium specimen and a description or illustration.

Registering and establishment of cultivar names is for over 50 years monitored by voluntary International Cultivar Registration Authorities ${ }^{39}$ (ICRAs) which focus on one or more plant genera. 
Many of them publish their cultivar register online. However, we only skimmed through these registers as other modus would not be in line with the scope of this paper that wishes to list genuine scientific eponymous taxa.

We, however, wish to share the history of the cultivar Vitis vinifera 'Leopold III' as it was very well documented by Derom (1987), unfortunately only in Dutch. It is a variety of red table grape, bred in 1937 by the Belgian grape breeder Emile Denayer from Hoeilaart, Belgium (see VIVC variety number 6808). According to Derom (1987), in 1925, Denayer saw a spontaneous mutation of striking size on a vine of the Vitis vinifera variety named 'Royal'. During the following 12 years he tried to inoculate this polyploid branch on different rootstocks. When he finally succeeded, in 1937, the new variety proved to be of exceptional quality and was rapidly sold in Europe and the USA and this through another Belgian breeder and salesman named Constantin Aerts. Mr. Aerts who had served in the First World War and was acquainted with Princess Henriette of Belgium, also known as the 'Duchess of Vendôme', sister of late King Albert I of Belgium and thus aunt of then King Leopold III. Princess Henriette brought the new cultivar to the attention of Leopold III, who responded with great interest to the idea of having this cultivar named after him. In December 1937, Leopold III formerly accepted this patronage (Derom 1987). Reference vouchers have subsequently been deposited in Italian, French and Spanish holding institutions, conform the obligations of the ICNCP. The presentday complete name of this tetraploid cultivar is: Vitis subgen. Euvitis vinifera Linnaeus 1753 subsp. vinifera 'Leopold III'.

In conclusion, we can state that the legacy of Astrid and Leopold III is still very visible today. For Astrid this is mainly through the eponyms attributed to her. For Leopold this is through his eponyms but also through the important reference collections he legged to the RBINS and the RMCA as well as to some other institutions. Sustainability in the legacy of Leopold III towards nature exploration and conservation is achieved through the KLFNEC, the chair of which continues to be at the RBINS. The latter institution has its collection tower decorated a 1.024 times by the emblem of King Leopold III in gold leaf.

\section{Acknowledgements}

We extend our thanks to the following colleagues of the RBINS: Dr. Wouter Dekoninck, Dr. Léon Baert and Stefan Kerkhof of the Entomology department for providing insights into the types under their care, Mrs. Katarzyna Smistek, Mrs. Camille Locatelli, Mr. Julien Lalanne and Mr. Jérôme Constant for coding, picturing and micro-CT scanning of several arachnids and insects, and Mrs. Isabelle Copée and the late Mrs. Isabelle Sauvage for providing access to the extensive library they have under their care; Dr. Karel Wouters, honorary head of the recent invertebrates section for providing detailed information on Cythereis reginaeastrid; Dr. Herman Goethals and Mrs. Marleen De Ceuckelaire of the Geology department for providing insights on the nomenclatural codes used for minerals and rocks; Dr. Annelise Folie of the Paleontology department for providing insights into the nomenclatural code used by geologists; Mrs. Camille Locatelli, Mrs. Florence Trus and Dr. Cédric d'Udekem d'Acoz for the imaging of some of the recovered invertebrate types; Mr. Jonathan Brecko for the imaging of several vertebrate types and Mrs. Brigitte Segers for her diligent and competent help in the compilation of a first draft of the eponyms list.

At the RMCA we are thankful to Dr. Didier VandenSpiegel for coordination of the search for eponymous types, to Mr. Stéphane Hanot for making some pictures of types and to Mr. Christophe Allard for making register numbers available. We further thank Dr. Frederik Leliaert (MBG) and Dr. Olivier De Clerck (University Gent) for providing insights on the cultivar code. The kind help of 
Mr. Jean-Pierre Dubois, science journalist, Science Press vzw, Mr. Michel Erkens and Mr. Stefaan Bockstal, respectively President and Secretary of the 'Koninklijke Heemkundige Kring Het Glazen Dorp vzw, Hoeilaart', for providing very useful data on the grape cultivar Vitis vinifera 'Leopold III', is also acknowledged.

Finally, we also thank an anonymous referee and especially Prof. Em. Dr. A. Dubois, Chief editor of Bionomina, for their constructive remarks and corrections on the first draft of this paper.

This work would not have been possible without the BelSPO project DIGIT 4, which liberated funds to digitize and put online of pictures and scans.

\section{Notes}

1 URL (accessed November 2020): https://www.cites.org/ (Website of CITES).

2 URL (accessed November 2020): https://www.cms.int/ (Website of CMS).

URL (accessed November 2020): https://www.cbd.int/ (Website of CBD).

4 URL (accessed November 2020): https://www.cbd.int/abs/ (Website of ABS/the Nagoya Protocol).

5 URL (accessed November 2020): https:/www.iczn.org/the-code/the-international-code-of-zoological-nomenclature/ the-code-online/ (Website with the online version of the zoological Code).

6 URL (accessed November 2020): https://www.iapt-taxon.org/nomen/main.php (Website with the online version of the ICN - the Shenzhen Code).

7 URL (accessed November 2020): https://www.microbiologyresearch.org/content/journal/ijsem/10.1099/ijsem. 0.000778 (Website with the online version of the ICNP).

8 URL (accessed November 2020): https://www.ishs.org/news/icncp-international-code-nomenclature-cultivatedplants-9th-edition (Website with the online version of the ICNCP).

9 URL (accessed November 2020): https://onlinelibrary.wiley.com/doi/abs/10.1111/avsc.12491 (Website with the online version of the ICPN).

10 URL (accessed November 2020): https://talk.ictvonline.org/information/w/ictv-information/383/ictv-code (Website with the online version of the ICVCN).

11 URL (accessed November 2020): http://cnmnc.main.jp/ (Website with the online version of the CNMNC).

12 URL (accessed November 2020): http://www.archives.biodiv.be/liii (Website of the King Leopold III Fund for Nature Exploration and Conservation).

13 URL (accessed October 2020): http://www.organismnames.com/ (Online database with taxon names derived from the Zoological Record).

14 URL (accessed January 2020): https://clarivate.libguides.com/webofscienceplatform/zr (Website of the Zoological Record).

15 The asterix is a wildcard that allows searching that is broader than leopoldi or astridae.

16 Dr. D. VandenSpiegel, pers. comm. to Y. Samyn, September 2015.

17 URL (accessed November 2020): http://www.naturalsciences.be/products/publications/ (Website with an overview of the in-house publications of the RBINS).

18 URL (accessed November 2020): http://www.africamuseum.be/research/publications/rmca/journals/JAZ (Website with an overview of the in-house publications of the RMCA).

19 URL (accessed November 2020): http://www.ipni.org/ (Online database with nomenclatural information of vascular plants).

20 URL (accessed November 2020): http://www.br.fgov.be/PUBLIC/GENERAL/publications.php (Website of MBG, partim publications).

21 URL (accessed November 2020): http://www.indexfungorum.org/ (Online database with the names of fungi, including yeasts, lichens, chromistan fungal analogues, protozoan fungal analogues and fossil forms, at all ranks).

22 URL (accessed November 2020): http://www.algaebase.org/ (Online database with taxonomic, nomenclatural and distributional information on algae).

23 URL (accessed November 2020): https://ucjeps.berkeley.edu/ina/ (Online database pertaining to algal taxonomy).

24 URL (accessed November 2020): https://www.diatombase.org/index.php (Online database pertaining to diatom taxonomy).

25 URL (accessed November 2020): http://cnmnc.main.jp/ (Online database pertaining to mineral names).

26 URL (accessed November 2020): https://www.ishs.org/news/icncp-international-code-nomenclature-cultivatedplants-9th-edition (Website with the online version of the ICNCP).

27 URL (accessed November 2020): https://www.azaleas.org/ (Online database pertaining to the names of azalea cultivars). 
28 URL (accessed November 2020): http://miklanek.tripod.com/MCS/cvA-E.html (Online list with cultivars of Sempervivum and Jovibarba).

29 URL (accessed November 2020): file://C:/Users/User/Downloads/InternationalRegisterupdated19June2016\%20(1). pdf (Online list of cultivars in Syringa).

30 URL (accessed November 2020): https://www.rhodogroup-rhs.org/docs/publications/rhodoregister/International\% 20Rhododendron $\% 20$ Register\%20Second\%20Edition $\% 20$ Volume $\% 202 \% 20$ Lem-Z\%20FOR $\% 20$ WEBSITE.pdf (Online list of rhododendron cultivars).

31 URL (accessed November 2020): https://www.rhs.org.uk/plants/search-Form (Online database to plant cultivars).

32 URL (accessed November 2020): http://databaze.dendrologie.cz/ (Online database to tree names).

33 URL (accessed November 2020): https:/virtualcollections.naturalsciences.be/ (Platform used by RBINS to liberate images of types and figured specimens).

34 URL (accessed November 2020): https://virtualcol.africamuseum.be (Platform used by RMCA to liberate images of types and figured specimens).

35 URL (accessed November 2020): http://www.botanicalcollections.be/\#/en/specimen/BR0000008538840.

36 URL (accessed November 2020): http://www.botanicalcollections.be/\#/en/specimen/BR0000006876258.

37 URL (accessed November 2020): List of Cultivars Sempervivum and Jovibarba, 2000: http://miklanek.tripod.com/ MCS/cvA-E.html.

38 URL (accessed November 2020): http://www.nv-asa.org/azaleas/2371/details?

39 URL (accessed November 2020): https://www.ishs.org/sci/icralist/icralist.htm.

40 URL (accessed May 2021): http://www.organismnames.com.

41 URL (accessed May 2021): http://www.archives.biodiv.be/liii/king/expeditions.

\section{Disclosure statement}

We declare no conflict of interest.

\section{References}

Alexander, C. P. (1937) Three Tipulidae collected in the East Indian Islands. Bulletin du Musée royal d'Histoire naturelle de Belgique, 13 (12): 1-3. [Description of Tipula (Formotipula) leopoldi].

Andrewes, H. E. (1932) Résultats scientifiques du voyage aux Indes Orientales Néerlandaises de LL.AA.RR. le Prince et la Princesse Léopold de Belgique: Coleoptera I, Carabidae. Mémoires du Musée royal d'Histoire naturelle de Belgique, 4 (4): 3-14. [Description of Lesticus leopoldi].

Attems, C. (1932) Résultats scientifiques du voyage aux Indes Orientales Néerlandaises de LL.AA.RR. le Prince et la Princesse Léopold de Belgique: Myriapoden. Mémoires du Musée royal d'Histoire naturelle de Belgique, 3 (12): 1-35, 6 pl. [Description of Platyrhacus principalis].

Baert, L. (1980) Spiders (Araneae) from Papua New Guinea. 1. Jocquella leopoldi gen. n., sp. n. (Telemidae). Bulletin of the British arachnological Society, 5 (1): 16-19. [Description of Jocquella leopoldi].

Bailey, L. H. (1923) Various cultigens, and transfers in nomenclature. Gentes Herbarum, 1: 113-136.

Ball, A. (1932) Résultats scientifiques du voyage aux Indes Orientales Néerlandaises de LL.AA.RR. le Prince et la Princesse Léopold de Belgique: Coleoptera I, Dytiscidae, Gyrinidae. Mémoires du Musée royal d'Histoire naturelle de Belgique, 4 (4): 21-23. [Description of Macrogyrus Leopoldi].

Balthasar, V. (1932) Deux nouveaux Sericini de Sumatra. Une contribution à la connaissance des Scarabaeidae de la région Orientale. Bulletin et Annales de la Société entomologique de Belgique, 72 (4): 113-117. [Description of Microserica leopoldiana and Neoserica principalis].

Bampps, P. \& Robyns, A. (1984) Spiranthera leopoldiana, Rutacée nouvelle de Bolivie. Bulletin du Jardin botanique national de Belgique, 54: 483-485. [Description of Spiranthera leopoldiana]. <https://doi.org/10.2307/3667855>.

Benthem Jutting, W. S. S. (1958) Sur un nouveau Mollusque terrestre, Aphanoconia leopoldi, de l'Île de Misool (Archipel Malais). Bulletin de l'Institut royal des Sciences naturelles de Belgique, 34 (25): 1-3. [Description of Aphanoconia Leopoldi].

Bequaert, J. (1932) Résultats scientifiques du voyage aux Indes Orientales Néerlandaises de LL.AA.RR. le Prince et la Princesse Léopold de Belgique: Hymenoptera I, Aculeata (Vespidae) Genre Ropalidia. Mémoires du Musée royal d'Histoire naturelle de Belgique, 4 (5): 47-51. [Description of Ropalidia leopoldi]. 
Bequaert, J. (1934) Les races de coloration de Vespa luctuosa De Saussure et de Polistes tenebricosus Lepeletier. Bulletin du Musée royal d'Histoire naturelle de Belgique, 10 (28): 1-11. [Description of Polistes tenebricosus var. Leopoldi].

Bequaert, M. (1940) Mydaidae du Congo belge. Bulletin du Musée d'Histoire naturelle de Belgique, 16 (30): 1-24. [Description of Mydaselpis leopoldi-tertii].

Betrem, J. G. \& Bradley, J. C. (1972) The African Campsomerinae (Hymenoptera, Scoliidae). Monografieën van de Nederlandse Entomologische Vereniging, 6: 1-326. [Description of Megameris (Penimeris) leopoldi and Megameris (Penimeris) leopoldi leopoldi].

Boschma, H. (1931) Résultats scientifiques du voyage aux Indes Orientales Néerlandaises de LL.AA.RR. le Prince et la Princesse Léopold de Belgique: Rhizocéphales. Mémoires du Musée royal d'Histoire naturelle de Belgique 3 (8): 2-7. [Description of Sacculina leopoldi].

Bosmans, R. (1982) Scientific report of the Belgian Mount Cameroon Expedition 1981. Situation of the collecting sites on the altitudinal gradient. Description of Hahnia leopoldi n. sp. (Araneae: Hahniidae). Revue de Zoologie africaine, 96 (3): 670-682. [Description of Hahnia leopoldi].

Bouillon, J. (1978) Hydroméduses de la mer de Bismarck (Papouasie, Nouvelle-Guinée). Partie 1: Anthomedusae Capitata (Hydrozoa, Cnidaria). Cahiers de Biologie marine, 19 (3): 249-297. [Description of Cnidocodon leopoldi].

Bourgoin, A. (1929) Voyage au Congo de S.A.R. le Prince Léopold de Belgique(1925). Part 1: Coleoptera, 6, Cétonides et Trichinides. Revue de Zoologie et de Botanique africaines 17: 100-106. [Description of Cymophorus Leopoldi and Gnatocera cruda var. Leopoldi].

Bourgoin, A. (1931a) Description préliminaire de deux Cétonides nouveaux recueillis au cours du voyage aux Indes Néerlandaises de LL.AA.RR. le Prince et la Princesse Léopold de Belgique. Bulletin du Musée royal d'Histoire naturelle de Belgique, 7 (26): 1-3. [Description of Coenochilus leopoldi and Macronota leopoldi].

Bourgoin, A. (1931b) Un Heterorrhina nouveau provenant des chasses au Congo belge de S.A.R. le Prince Léopold de Belgique. Revue de Zoologie et Botanique africaines, 20 (3): 305-306. [Description of Heterorrhina Leopoldi].

Bouvier, E.-L. (1930) Saturnioïdes rapportés du Congo belge par S.M. la Reine Elisabeth de Belgique. Revue de Zoologie et de Botanique africaines, 17 (4): 394-404. [Description of Bunea leopoldi].

Brongersma, L. D. (1930) Sur un Geckonidae nouveau Gehyra Leopoldi nov. sp. de la Nouvelle Guinée. Bulletin du Musée royal d'Histoire naturelle de Belgique, 6 (11): 1-3. [Description of Gehyra leopoldi].

Brongersma, L. D. (1932) Suppression of the name Paraperipatus leopoldi Leloup (Onychophora). Entomologische Berichten, 8: 410-41.

Burgeon, L. (1932) Résultats scientifiques du voyage aux Indes Orientales Néerlandaises de LL.AA.RR. le Prince et la Princesse Léopold de Belgique: Coleoptera I, Lucanidae. Mémoires du Musée royal d'Histoire naturelle de Belgique, 4 (4): 75-82. [Description of Spinanomala leopoldi].

Burgeon, L. (1935) Coléoptères, Carabides (première partie). In: Catalogues raisonnés de la Faune entomologique du Congo belge, (série 3, section 2), 2 (3): 131-257. [Description of Chlaenius (Chlaeniostenus) Leopoldi].

Burgeon, L. (1946) Melolonthini et Pachydemini du Congo belge (Coleopt. Scarab. Melolonthinae). Revue de Zoologie et de Botanique africaines, 39 (3): 230-273. [Description of Anartioschiza Leopoldi].

Castex, M. N. \& Castello, H. P. (1970) Potamotrygon leopoldi, a new species of freshwater sting-ray for the Xingú River, Brazil (Chondrichthyes, Potamotrygonidae). Acta scientifica, Universidad del Salvador, 10: 1-16. [Description of Potamotrygon leopoldi].

Cheesman, L. E. (1932) Résultats scientifiques du voyage aux Indes Orientales Néerlandaises de LL.AA.RR. le Prince et la Princesse Léopold de Belgique: Hymenoptera I, Ichneumonoidea. Mémoires du Musée royal d'Histoire naturelle de Belgique, 4 (5): 55-59. [Description of Mesostenoideus leopoldi].

Chopard, L. (1931) Résultats scientifiques du voyage aux Indes Orientales Néerlandaises de LL.AA.RR. le Prince et la Princesse Léopold de Belgique: Heterometabola I, Gryllidae et Gryllacridae. Mémoires du Musée royal d'Histoire naturelle de Belgique, 4 (1): 5-22. [Description of Lebinthus Leopoldi].

Cockerell, T. D. A. (1933) Bees from the Belgian Congo: a new Anthophora obtained in the Kivu District by S.A.R. le Prince Léopold. Revue de Zoologie et de Botanique africaines, 22 (4): 360-361. [Description of Anthophora leopoldi].

Curran, C. H. (1929) Voyage au Congo de S.A.R. le Prince Léopold de Belgique (1925), part 2: Diptera 4, Dolichopodides, Bombylides, Mycétophilides, Diopsides et Muscides. Revue de Zoologie et Botanique africaines, 17 (2): $245-248$. [Description of Caricea leopoldi].

Debauche, H. R. (1938) Geometridae (Lep. Het.). Exploration du Parc National Albert, Mission G. F. de Witte (19331935), 20: 2-56. [Description of Xanthorhoe leopoldi].

Debauche, H. R. (1942) Lepidoptera, Heterocera. Exploration du Parc National Albert, Mission G. F. De Witte (19331935), 41: 1-28. [Description of Spilosoma leopoldi].

De Freina, J. \& De Prins, W. (2018) Nomenclatural and taxonomic notes on three South-East Asian species of Amata (Lepidoptera: Erebidae: Arctiinae: Syntomini). Zootaxa, 4461 (1): 141-145. <https://doi.org/10.11646/ zootaxa.4461.1.11>.

Derom, M. (1987) Figuren uit ons dorp: Emile Denayer-Vanmoer (Miel van Miskens). Zoniën, 1987 (1): $50-64$.

Desbordes, H. (1929) Voyage au Congo de S.A.R. le Prince Léopold de Belgique (1925), part 1: Coleoptera, 5, Description 
d'une nouvelle espèce d'Histérides. Revue de Zoologie et de Botanique africaines, 17 (1): 98-99. [Description of Hister s.str. Leopoldi].

Derenne M. F. (1926) Aberrations de Lépidoptères (suite). Lambillionea, Revue mensuelle de l'Union des Entomologistes belges, 10: 73-74. [Description of Vanessa io ab. astrida].

Deuquet, C. M. (1938) Description of three new species of Stigmodera (Buprestidae). The Proceedings of the Linnaean Society of New South Wales, 63: 305-307. [Description of Stigmodera (Castiarina) astridae].

Didier, R. (1932) Résultats scientifiques du voyage aux Indes Orientales Néerlandaises de LL.AA.RR. le Prince et la Princesse Léopold de Belgique: Coleoptera I, Lucanidae. Mémoires du Musée royal d'Histoire naturelle de Belgique, 4 (4): 41-48. [Description of Aegus leopoldi and Dorcus astridae].

Diederich, P. \& Scheidegger, C. (1996) Reichlingia leopoldii gen. et sp. nov., a new lichenicolous hyphomycete from central Europe. Bulletin de la Société des Naturalistes luxembourgeois, 97: 3-8. [Description of Reichlingia leopoldi].

Dijkstra, K.-D. B., Clausnitzer, V, \& Vick, G. S. (2006) Revision of the three-striped species of Phyllogomphus (Odonata, Gomphidae). Tijdschrift voor Entomologue, 149: 1-14. [Nomenclatural decision on Phyllogomphus leopoldi]. $<$ https:// doi.org/10.1163/22119434-900000183>.

Dupuis, P. (1931) Description de Mollusques nouveaux recueillis au cours du voyage de S.A.R. le Prince Léopold de Belgique aux Indes Orientales Néerlandaises (1ère note). Bulletin du Musée royal d'Histoire naturelle de Belgique, 7 (9): 1-8. [Description of Ameria leopoldi and Papuina astridae].

Elsen, P. (1972) Sept nouvelles espèces de Neocypholaelaps Vitzthum, 1941 (Mesostigmata: Ameroseiidae) phorétiques d'Hyménoptères africains. Revue de Zoologie et de Botanique africaines, 86 (1-2): 17-30. [Description of Neocypholaelaps leopoldi].

Engel, H. (1938) Résultats scientifiques du voyage aux Indes Orientales Néerlandaises de LL.AA.RR. le Prince et la Princesse Léopold de Belgique: Astéries et Ophiures. Mémoires du Musée royal d'Histoire naturelle de Belgique, 3 (18): 3-31. [Description of Culcita novae-guinea var. leopoldi and Ophidiaster astridae].

Fain, A. (1955) Sur le parasitisme des fosses nasales chez les Mammifères et les Oiseaux par les Acariens de la famille Speleognathidae (Acarina). Description d'une espèce nouvelle chez la sauve-souris. Annales de la Société belge de Médecine tropicale, 35 (6): 689-698 [Description of Astrida].

Fain, A. (1956) Les Acariens de la famille Rhinonyssidae Vitzthum 1935 parasites des fosses nasales des Oiseaux au Ruanda-Urundi. (Note preliminaire). Revue de Zoologie et de Botanique africaines, 53: 131-157. [Description of Ptilonyssus astridae].

Fain, A. (1957a) Essai de classification des Rhinonyssidae (Acari: Mesostigmata) avec description de deux genres nouveaux. Annales de Parasitologie humaine et comparée, 31 (1-2): 145-157. [Description of Astridiella].

Fain,A. (1957b) Les Acariens du genre Astridiella n. g. (Rhinonyssidae) parasites nasicoles de l'engoulevent et de l'Outarde. Rivista di Parasitologia, 18 (2): 91-102. [Description of Astridiella with proposal of a new type specimen].

Fain, A. (1957c) Deux nouveaux Acariens parasites nasicoles du Porc-Epic au Congo belge. Revue de Zoologie et de Botanique africaines, 55 (1-2): 69-81. [Description of Rhinophaga leopoldi].

Fain, A. (1959) Les Acariens psoriques parasites des Chauves-souris. IV. Le genre Teinocoptes Rodhain. Création d'une nouvelle famille: Teinocoptidae (Sarcoptiformes). Revue de Zoologie et de Botanique africaines, 59 (1-2): 118-136. [Description of Teinocoptes astridae].

Fain, A. (1962) Les Acariens parasites nasicoles des Batraciens. Révision des Lawrencarinae Fain, 1957 (Ereynetidae: Trombidiformes). Bulletin de l'Institut royal des Sciences naturelles de Belgique, 38 (25): 1-69. [Description of Neastrida Fain, 1962]. <https://doi.org/10.1007/BF00260166>.

Fain, A. (1974) Mission zoologique du Fonds Léopold III en Irian (Nouvelle-Guinée Occidentale): Acariens parasites de Marsupiaux et de Rongeurs (Listrophoroidea). Bulletin de l'Institut royal des Sciences naturelles de Belgique, Entomologie, 50 (7): 1-22. [Description of Murichirus (Murichirus) leopoldi].

Fain, A. (1985) Systematic notes on the Speleognathinae (Acari, Ereynetidae) with description of new taxa and a key to the Trispeleognathini. Bulletin et Annales de la Societé royale belge d'Entomologie, 12: 143-152. [Neastrida raised from subgeneric to generic level].

Fisher, W. S. (1934) Malaysian Cerambycidae (Coleoptera). Bulletin du Musée royal d'Histoire naturelle de Belgique, 10 (15): 1-6. [Description of Daphysia leopoldi].

Fraser, F. C. (1932) Résultats scientifiques du voyage aux Indes Orientales Néerlandaises de LL.AA.RR. le Prince et la Princesse Léopold de Belgique: Heterometabola II, Odonata. Mémoires du Musée royal d'Histoire naturelle de Belgique, 4 (3): 5-34. [Description of Neurobasis leopoldi and Procordulia leopoldi].

Frétey, T. (2019) Capitalised epithets in the works of Linnaeus (1758-1767): findings and consequences in herpetology. Bionomina, 16: 22-45. <https://doi.org/10.11646/bionomina.16.1.2>.

Gebien, H. (1935) Résultats scientifique du voyage aux Indes Orientales Néerlandaises de LL.AA.RR. le Prince et la Princesse Leopold de Belgique: Coleoptera III, Tenebrionidae. Mémoires du Musée royal d'Histoire naturelle de Belgique, 4 (11): 53-77. [Description of Aptermerus Leopoldi].

Gery, J., Planquette, P. \& Le Bai, P. Y. (1988) Un nouveau Tetragonopterinae (Pisces, Characoidei, Characidae) de la Guyane: Astyanax leopoldi sp. n. Revue francaise d'Aquariologie et Herpétologie, 15 (1): 9-12. [Description of Astynax leopoldi]. 
Ghesquière, J. (1933) Variations et aberrations de Lépidoptères (suite). Sur deux races nouvelles de Charaxes smaragdalis Btlr. (Nymph.). Lambillionea, 33 (4): 3-6. [Description of Charaxes smaragdalis f. reg. Leopoldi].

Ghesquière, J. (1942) Catalogues raisonnés de la faune entomologique du Congo belge. Lépidoptères, Microlépidoptères. Annales du Musée du Congo belge, Zoologie, (série 3, 2), 7: 1-120. [Description of Bradina Leopoldi-III].

Giltay, L. (1929) Notes préliminaires sur les poissons recueillis aux Indes Néerlandaises par S.A.R. le Prince Léopold de Belgique: I. Diaphus Astridae, nov. sp., Myctophidae nouveau des côtes de la Nouvelle-Guinée. Annales de la Société royale zoologique de Belgique, 60: 29-32. [Description of Diaphus Astridae].

Giltay, L. (1930) Notes préliminaires sur les Opilions recueillis aux Indes Néerlandaises par S.A.R. Le Prince Léopold de Belgique. Annales et Bulletin de la Société entomologique de Belgique, 69: 419-429. [Description of Gagrella Leopoldi, Paradampetrus Leopoldi].

Giltay, L. (1933) Résultats scientifiques du voyage aux Indes Orientales Néerlandaises de LL.AA.RR. le Prince et la Princesse Léopold de Belgique: poissons. Mémoires du Musée royal d'Histoire naturelle de Belgique, 5 (3): 1-129. [Description of Synchinopus leopoldi].

Giltay, L. (1935) Liste des Arachnides d'Extrême-Orient et des Indes Orientales recueillis, en 1932, par S.A.R. le Prince Léopold de Belgique. Bulletin du Musée royal d'Histoire naturelle de Belgique, 11 (20): 1-15. [Description of Scytodes leopoldi].

Goetghebuer, M. (1932) Résultats scientifiques du voyage aux Indes Orientales Néerlandaises de LL.AA.RR. le Prince et la Princesse Léopold de Belgique: Diptera I, Ceratopgonidae et Chironomidae. Mémoires du Musée royal d'Histoire naturelle de Belgique, 4 (7): 5-7. [Description of Polypedilum leopoldi].

Gordon, I. (1934) Résultats scientifiques du voyage aux Indes Orientales Néerlandaises de LL.AA.RR. le Prince et la Princesse Léopold de Belgique: Crustacea, Brachyura. Mémoires du Musée royal d'Histoire naturelle de Belgique, 3 (15): 3-78. [Description of Parapilumnus leopoldi].

Gosse, J-P. (1963) Description de deux Cichlides nouveaux de la région Amazonienne. Bulletin de l'Institut royal des Sciences naturelles de Belgique, 39 (35): 1-7. [Description of Plataxoides leopoldi].

Hanitsch, R. (1931) Résultats scientifiques du voyage aux Indes Orientales Néerlandaises de LL.AA.RR. le Prince et la Princesse Léopold de Belgique: Heterometabola I, Blattidae. Mémoires du Musée royal d'Histoire naturelle de Belgique, 4 (1): 41-60. [Description of Macrocerca leopoldi].

Hering, M.(1929) Voyage au Congo de S.A.R. le Prince Léopold de Belgique (1925), part 2: Lepidoptera. 4. Description d'un Lasiocampide nouveau (Lechriolepis leopoldi nov. spec.). Revue de Zoologie et Botanique africaines, 17 (2):237239. [Description of Lechriolepis leopoldi].

Hering, M. (1934) Syntomididae aus dem Brüsseler Museum. Bulletin du Musée royal d'Histoire naturelle de Belgique, 10 (21): 1-5. [Description of Leopoldina, Leopoldina leopoldi and Syntomis leopoldi].

Hunter, T. B., Peltier, L. F. \& Lund, P. J. (2000) Radiologic history exhibit. Musculoskeletal eponyms: who are those guys? RadioGraphics, 20 (3): 819-836. <https://doi.org/10.1148/radiographics.20.3.g00ma20819>.

Invrea, F. (1934) Résultats scientifiques du voyage aux Indes Orientales Néerlandaises de LL.AA.RR. le Prince et la Princesse Léopold de Belgique: Hymenoptera II, Chrysididae. Mémoires du Musée royal d'Histoire naturelle de Belgique, 4 (10): 33-34. [Description of Chrysis (Trichrysis) singalensis Leopoldi].

Jacquemart, S. (1981) Un Trichoptère Philopotamide nouveau de Nouvelle-Guinée (Irian Jaya): Chimarra leopoldi sp. n. Bulletin de l'Institut royal des Sciences naturelles de Belgique, Entomologie, 53 (5): 1-6. [Description of Chimarra leopoldi].

Janse, A. J. T. (1935) Résultats scientifiques du voyage aux Indes Orientales Néerlandaises de LL.AA.RR. le Prince et la Princesse Léopold de Belgique: Lepidoptera II, Pyralidae. Mémoires du Musée royal d'Histoire naturelle de Belgique, 4 (12): 3-18. [Description of Coptobasoides léopoldi].

Kemner, N. A. (1933) Résultats scientifiques du voyage aux Indes Orientales Néerlandaises de LL.AA.RR. le Prince et la Princesse Léopold de Belgique: Heterometabola III, Isoptera. Mémoires du Musée royal d'Histoire naturelle de Belgique, 4 (8): 19-30. [Description of Schedorhinotermes longirostris var. Leopoldi].

Kiriakoff, S. G. (1948) Recherches sur les organes tympaniques des Lépidoptères en rapport avec la classification I. Ctenuchidae. Bulletin et Annales de la Société royale entomologique de Belgique, 84 (11-12): 231-276. [Description of the genus Astridia].

Knapp, S., Lamas, G., Lughadha, E. N \& Novarino, G. (2004) Stability or stasis in the names of organisms: the evolving codes of nomenclature. Philosophical Transactions of the royal Society of London, (B), 359: 611-622. < https://doi. org/10.1098/rstb.2003.1445>.

Labarque, F. M., Grismado, C. J., Ramirez, M. J., Yan, H. \& Griswold, C. E. (2009) The Southeast Asian genus Stedocys Ono, 1995 (Aranae: Scytodidae): first descriptions of female genitalia and a new species from China. Zootaxa, 2297: 1-14. <https://doi.org/10.11646/zootaxa.2297.1.1>.

Labbé, A. (1934) Résultats scientifiques du voyage aux Indes Orientales Néerlandaises de LL.AA.RR. le Prince et la Princesse Léopold de Belgique: Opistiobranches et Silicodermés (Oncidiadés). Mémoires du Musée royal d'Histoire naturelle de Belgique, 2 (14): 1-83. [Description of Oncidium Astridae, Oncidium Leopoldi].

Laboissière, V. (1929) Voyage au Congo de S.A.R. le Prince Léopold de Belgique (1925), part 2: Coleoptera, 18. Chrysomelidae. Revue de Zoologie et de Botanique africaines, 17: 137-153. [Description of Barombia Leopoldi, 
Mahutia Leopoldi].

Laboissière, V. (1931) Galerucini (Coleoptera Chrysomeidae) d'Angola. Revue suisse de Zoologie, 38 (23): $405-418$. [Introduction of Barombiella, nom.nov. to replace Barombia]. <https://doi.org/10.5962/bhl.part.117646>.

Laboissière, V. (1932) Résultats scientifiques du voyage aux Indes Orientales Néerlandaises de LL.AA.RR. le Prince et la Princesse Léopold de Belgique: Coleoptera I, Galerucinae. Mémoires du Musée royal d'Histoire naturelle de Belgique, 4 (23): 145-184. [Description of Arcastes astridae, Astridella, Astridella cyanapennis, Oides leopoldi, Neodrana leopoldi and Cassenea leopoldi].

Laboissière, V. (1934) Quelques Galerucinae de l'Orient. Bulletin du Musée royal d'Histoire naturelle de Belgique, 10 (37): 1-4. [Description of Aulacophora leopoldi].

Lallemand, V. (1931) Résultats scientifiques du voyage aux Indes Orientales Néerlandaises de LL.AA.RR. le Prince et la Princesse Léopold de Belgique: Heterometabola I, Hemiptera-Homoptera. Mémoires du Musée royal d'Histoire naturelle de Belgique, 4 (1): 71-85. [Description of Convarcia leopoldi, Cryptotympana leopoldi, Clovia leopoldi and Hemisphaerius astridae].

Le Cerf, F. (1933) Quelques Lépidoptères Hétérocères récoltés aux Indes Orientales et au Congo par S.A.R. le prince Léopold de Belgique. Bulletin du Musée royal d'Histoire naturelle de Belgique, 9 (33): 1-3. [Description of Philosomia Cynthia canningi ssp. Leopoldi].

Leloup, E. (1930) Sur un Hydropolype nouveau, Thecocarpus leopoldi nov. sp., des Indes Orientales Néerlandaises. Bulletin du Musée royal d'Histoire naturelle de Belgique 6 (1): 1-3. [Description of Thecocarpus leopoldi].

Leloup, E. (1931) Résultats scientifiques du voyage aux Indes Orientales Néerlandaises de LL.AA.RR. le Prince et la Princesse Léopold de Belgique: Paraperipatus leopoldi nov. nom. Mémoires du Musée royal d'Histoire naturelle de Belgique, 2 (9): 3-14. [Description of Paraperipatus leopoldi].

Leloup, E. (1933) Résultats scientifiques du voyage aux Indes Orientales Néerlandaises de LL.AA.RR. le Prince et la Princesse Léopold de Belgique: Brachiopodes et Amphineures. Mémoires du Musée royal d'Histoire naturelle de Belgique, 2 (13): 7-33, pl. 1-2. [Description of Aacanthochitona leopoldi].

Lestage, J.A. (1934) Notes sur l'entomofaune indochinoise. IV. Une nouvelle Climaciella du Tonkin (Climaciella Leopoldi) et remarques sur le rôle des Mantispidés en phytopathologie. Bulletin et Annales de la Société royale entomologique de Belgique, 74: 153-160. [Description of Climaciella Leopoldi].

Lieftinck, M. A. (1935) New and little known Odonata of the Oriental and Australian Regions. Treubia, 15: $175-207$. [Description of Procordulia astridae].

Linnaeus, C. (1753) Species plantarum. Tomus 1. Holmiae (Laurentii Salvii): [i-xii] + 1-560.

Malloch, J. R. (1934) Résultats scientifiques du voyage aux Indes Orientales Néerlandaises de LL.AA.RR. le Prince et la Princesse Léopold de Belgique: Diptera II, Cyclorrhapha: Muscidae, Calliphoridae and Tachinidae. Mémoires du Musée royal d'Histoire naturelle de Belgique, 4 (10): 5-24. [Description of Euphumosia leopoldi].

Marshall, G. A. K. (1935) Résultats scientifiques du voyage aux Indes Orientales Néerlandaises de LL.AA.RR. le Prince et la Princesse Léopold de Belgique: Coleoptera III, Curculionidae. Mémoires du Musée royal d'Histoire naturelle de Belgique, 4 (11): 35-50. [Description of Coptorrhynchus leopoldi].

Maulik, S. (1935) Résultats scientifiques du voyage aux Indes Orientales Néerlandaises de LL.AA.RR. le Prince et la Princesse Léopold de Belgique: Coleoptera III, Chrysomelidae. Mémoires du Musée royal d'Histoire naturelle de Belgique, 4 (11): 3-34. [Description of Sphaeroderma leopoldi].

Meuffels, H. J. G. \& Grootaert, P. (1984) Dolichopodidae (Diptera) from Papua New Guinea I: the genus Cymatopus Kertész with a discussion on Abatetia Miller and Cemocarus gen. nov. Indo-Malayan Zoology, 1 (1): $141-158$. [Description of Cymatopus leopoldi].

Michaelsen, W. (1930) Diagnosen Einiger Neuer Oligochäten Aus Sumatra. Bulletin du Musée d'Histoire naturelle de Belgique, 6 (2): 1-6. [Description of Pheretima (Pherithima) leopoldi].

Michaelsen, W. (1932) Neue Oligochaeten Von Bali Und Borneo. Bulletin du Musée d'Histoire naturelle de Belgique, 7 (32): 1-11. [Description of Pheretima (Pherithima) principalis].

Navas, R. P. L. (1931) Résultats scientifiques du voyage aux Indes Orientales Néerlandaises de LL.AA.RR. le Prince et la Princesse Léopold de Belgique: Neuroptera, Mantispidaea. Mémoires du Musée royal d'Histoire naturelle de Belgique, 4 (2): 9-10. [Description of Neclya leopoldi].

Navas, R. P. L. (1932) Insectes du Congo Belge. Revue de Zoologie et Botanique africaines, 22 (3): 269-290. [Description of Neoperla leopoldina].

Nierstrasz, H. F. (1930) Résultats scientifiques du voyage aux Indes Orientales Néerlandaises de LL.AA.RR. le Prince et la Princesse Léopold de Belgique: I. Isopoda (excl. Oniscoidea et Epicaridea). Mémoires du Musée royal d'Histoire naturelle de Belgique, 3 (1): 3-11. [Description of Tachaea leopoldi].

Nierstrasz, H. F. \& Brender à Brandis, G. A. (1930) Résultats scientifiques du voyage aux Indes Orientales Néerlandaises de LL.AA.RR. le Prince et la Princesse Léopold de Belgique: II. Isopoda, Epicaridea. Mémoires du Musée royal d'Histoire naturelle de Belgique, 3 (1): 12-17. [Description of Parioninella astridae].

Overlaet, F. G. (1944) Formes nouvelles ou peu connues de Nymphalides africains. II. Revue de Zoologie et de Botanique africaines, 38 (1): 40-74. [Description of Cymothoe excelsa ssp. Regis-Leopoldi].

Parent O. (1932) Résultats scientifiques du voyage aux Indes Orientales Néerlandaises de LL.AA.RR. le Prince et la 
Princesse Léopold de Belgique: Diptera I, Dolichopodidae. Mémoires du Musée royal d'Histoire naturelle de Belgique, 4 (7): 23-25. [Description of Chrysosoma leopoldi].

Pauwels, I. \& Pieters, G. (2011) Hortensia en haar zusjes: groeien, bloeien, sproeien, snoeien. Tielt (Uitg. Lannoo): $1-120$.

Pic, M. (1929a) Voyage au Congo de S.A.R. le Prince Léopold de Belgique (1925), part 2: Coleoptera, 28, Lycides, Lampyrides, Téléphorides et Clérides. Revue de Zoologie et de Botanique africaines, 17 (2): 181-183. [Description of Silidius Leopoldi].

Pic, M. (1929b) Voyage au Congo de S.A.R. le Prince Léopold de Belgique (1925), part 1: Coleoptera, 11. Méloides et Horiides. Revue de Zoologie et de Botanique africaines, 17 (1): 116-118. [Description of Zonabris amplectans var. nov. Leopoldi].

Pic, M. (1931) Coléoptères Malacodermes Hétéromères nouveaux. Revue de Zoologie et de Botanique africaines, 21 (1): 37-50. [Description of Diaphanes latipennis var. Leopoldi].

Pic, M. (1932a) Résultats scientifiques du voyage aux Indes Orientales Néerlandaises de LL.AA.RR. le Prince et la Princesse Leopold de Belgique: Coleoptera I, Heteromera (ex parte). Mémoires du Musée royal d'Histoire naturelle de Belgique, 4 (4): 117-119. [Description of Lagria Leopoldi].

Pic, M. (1932b) Résultats scientifiques du voyage aux Indes Orientales Néerlandaises de LL.AA.RR. le Prince et la Princesse Léopold de Belgique: Coleoptera I, Malacodermata. Mémoires du Musée royal d'Histoire naturelle de Belgique, 4 (4): 85-89. [Description of Cladophorus Leopoldi, Trichalus Leopoldi and Laius Leopoldi].

Pic, M. (1933) Coléoptères malacodermes et vésicants orientaux recueillis en 1932 par S.A.R. le Prince Léopold de Belgique. Bulletin du Musée royal d'Histoire naturelle de Belgique, 9 (35): 1-4. [Description of Athemus Astridae and Dascillus Leopoldi].

Pic, M. (1952) Coléoptères nouveaux du Congo Belge. Annales du Musée royal du Congo belge Tervuren (Belgique), (8), 12: 5-47. [Description of Ptilodactyla Leopoldi].

Pic, M. (1955) Contributions à l'étude de la faune entomologique du Ruanda-Urundi (Mission P. Basilewsky 1953). LX. Coleoptera Lampyridae, Drilidae, Melyridae, Dasytidae, Cantharididae, Malachiidae. Annales du Musée royal du Congo Belge Tervuren (Belgique), (série in- $8^{\circ}$, Sciences zoologiques), 40: 156-174. [Description of Silidius Astridae var. urundensis].

Quinlan, J. (1979) A revisionary classification of the Cynipoidea (Hymenoptera) of the Ethiopian zoogeographical region. Aspicerinae (Figitidae) and Oberthuerellinae (Liopteridae). Bulletin of the British Museum of natural History (Entomology), 39 (2): 85-133. [Description of Anacharoides astrida].

Roepke, W. (1932) Résultats scientifiques du voyage aux Indes Orientales Néerlandaises de LL.AA.RR. le Prince et la Princesse Léopold de Belgique: Lepidoptera I, Heterocera. Mémoires du Musée royal d'Histoire naturelle de Belgique, 4 (6): 79-99. [Description of Careades hemichlora leopoldina].

Roewer, C. F. (1938) Résultats scientifiques du voyage aux Indes Orientales Néerlandaises de LL.AA.RR. le Prince et la Princesse Léopold de Belgique: Araneae. Mémoires du Musée royal d'Histoire naturelle de Belgique, 3 (19): 3-94. [Description of Nicodamus leopoldi, Plotius leopoldi and Telomonia leopoldi].

Ruhberg, H. (1985) Die Peripatopsidae (Onychophora). Systematik, Okologie, Chorologie und phylogenetische Aspekte. In: F. Schaller (ed.), Zoologica, Heft 137, Stuttgart (E. Schweizerbartïsche Verlagsbuchhandlung): 1-184.

Samyn, Y. \& De Clerck, O. (2012) No name, no game. European Journal of Taxonomy, 10: 1-3. <https://doi.org/10.5852/ ejt.2012.10>.

Samyn, Y., Kerr, A. M., O’Loughin, M., Massin, C., Pawson, D. L., Rowe, F. W. E., Smiley, S., Solis-Marin, F., Thandar, A.S., Van den Spiegel, D. \& Paulay, G. (2010) Using sea cucumbers to illustrate the basics of zoological nomenclature. SPC Beche-de-mer Information Bulletin, 30: 33-40.

Samyn, Y., Segers, B. \& Van Goethem, J. (2016) Eponiemen ter ere van Hunne Koninklijke Hoogheden Astrid en Leopold III van België. Museum Dynasticum, 28 (2016-1): 13-20, 7 coll. fig.

Santschi, F. (1932) Résultats scientifiques du voyage aux Indes Orientales Néerlandaises de LL.AA.RR. le Prince et la Princesse Léopold de Belgique: Hymenoptera I, Formicidae. Mémoires du Musée royal d'Histoire naturelle de Belgique, 4 (5): 11-29. [Description of Polyrhachis (Chariomyrma) leopoldi and Pseudolasius leopoldi].

Schouteden, H. (1916) Palophus Leopoldi n. sp. (Orthoptera Phasmidae). Revue Zoologique africaine, 4 (2-3): $265-268$. [Description of Palophus Leopoldi]. <https://doi.org/10.5962/bhl.part.13898>.

Schouteden, H. (1929a) Voyage au Congo de S.A.R. le Prince Léopold de Belgique (1925), part 1: Hemiptera, 1. Coptosomatides et Pentatomides. Revue de Zoologie et de Botanique africaines, 17 (1): 57-65. [Description of Laccophorella leopoldi].

Schouteden, H. (1929b) Voyage au Congo de S.A.R. Le Prince Léopold de Belgique (1925), part 1: Hemiptera, 2. Fam. Coreidae (Lygaeidae). Revue de Zoologie et de Botanique africaines, 17 (1): 66-71. [Description of Acanthocoris Leopoldi].

Schouteden, H. (1929c) Voyage au Congo de S.A.R. le Prince Léopold de Belgique (1925), part 1: Hemiptera, 4. Fam. Reduviidae. Revue de Zoologie et de Botanique africaines, 17 (1): 75-81. [Description of Oncocephalus Astridae, Oncocephalus Leopoldi and Breddina leopoldi].

Schouteden, H. (1933) Résultats scientifiques du voyage aux Indes Orientales Néerlandaises de LL.AA.RR. le Prince et 
la Princesse Léopold de Belgique: Heterometabola III, Hemiptera-Heteroptera. Mémoires du Musée royal d'Histoire naturelle de Belgique, 4 (8): 43-70. [Description of Agapophyta Astridae, Antilochus Astridae, Halyomorpha Leopoldi, Geocoris Leopoldi, Conorhinus Leopoldi and Ceratopirates Leopoldi].

Sena Oliveira, I. de, Morley St. J. Read, V. \& Mayer, G. (2012) A world checklist of Onychophora (velvet worms), with notes on nomenclature and status of names. Zookeys, 211: 1-70. <https://doi.org/10.3897/zookeys.211.3463>.

Sicard, A., Mader, L. \& Arrow, G.J. (1933) Résultats scientifiques du voyage aux Indes Orientales Néerlandaises de LL.AA.RR. le Prince et la Princesse Léopold de Belgique: Coccinellidae. Mémoires du Musée royal d'Histoire naturelle de Belgique, 4 (9): 51-57. [Description of Coccinella leopoldi].

Sirenko, B. I. \& Tai, T. H. (2020) First findings of the rare chiton Acanthochitona leopoldi (Mollusca: Polyplacophora) in the South China Sea. Zoosystematica rossica, 29 (1): 93-100 [Redescription of Acanthochites leopoldi]. <https://doi. org/10.31610/zsr/2020.29.1.93>.

Sjöstedt, Y. (1929) Voyage au Congo de S.A.R. le Prince Léopold de Belgique (1925), part 1: Orthoptera, 1, Acridiodea. Revue de Zoologie et de Botanique africaines, 17 (1): 21-37. [Description of Kivuia Leopoldi)

Sjostedt, Y. (1934) Acrididen aus Kongo. Bulletin du Musée d'Histoire naturelle de Belgique, 10 (4): 1-5. [Description of Acrida leopoldi].

Tams, W. H. T. (1935) Résultats scientifiques du voyage aux Indes Orientales Néerlandaises de LL.AA.RR. le Prince et la Princesse Léopold de Belgique: Lepidoptera II, Heterocera. Mémoires du Musée royal d'Histoire naturelle de Belgique, 4 (12): 33-64. [Description of Diacrisia leopoldi, Eilema leopoldi, Gastropacha pardale leopoldi, Nyctemera leopoldi, Odonedstis vita leopoldi, Syntomis leopoldi and Trabala leopoldi].

Théry, A. (1929) Voyage au Congo de S.A.R. le Prince Léopold de Belgique (1925), part 2: Coleoptera, 25, Fam. Buprestidae. Revue de Zoologie et de Botanique africaines, 17 (2): 175-178. [Description of Damarsila umbrosa ssp. Leopoldi].

Tehler, A., Ertz, D. \& Irestedt, M. (2013) The genus Dirina (Rocecellaceae, Arthoniales) revisited. The Lichenologist, 54 (4): 427-476. [Description of Dirina astridae]. <https://doi.org/10.1017/S0024282913000121>.

Théry, A. (1932) Résultats scientifiques du voyage aux Indes Orientales Néerlandaises de LL.AA.RR. le Prince et la Princesse Léopold de Belgique: Coleoptera I, Buprestidae. Mémoires du Musée royal d'Histoire naturelle de Belgique, 4 (4): 97-106. [Description of Chrysodema radians ssp. Leopoldi].

Théry, A. (1933) Bupréstides récoltés par son Altesse royale le Prince Léopold de Belgique. Bulletin du Musée royal d'Histoire naturelle de Belgique, 9 (31): 1-4. [Description of Chrysodema leopoldiana].

Thiel, M. E. (1932) Résultats scientifiques du voyage aux Indes Orientales Néerlandaises de LL.AA.RR. le Prince et la Princesse Léopold de Belgique: Madreporaria. Mémoires du Musée royal d'Histoire naturelle de Belgique, 2 (12): 1-177. [Description of Seriatopora leopoldi and Porites astridae].

Van den Berghe, L., Chardome, M. \& Peel, E. (1957) The filarial parasites of the eastern gorilla in the Congo. Journal of Helmithology, 38 (3-4): 349-368, 1 pl. [Description of Microfilaria Leopoldi]. <https://doi.org/10.1017/ S0022149X00033903>.

Van Goethem, J. L. \& Samyn Y. (in press) History and highlights of the King Leopold III Biological Station Laing Island. In: P. Bouchet, C. Payri, R. Sabroux \& S. Samadi (ed), The marine fauna and flora of the Bismarck Sea, Paris (MNHN, Patrimoines Naturels).

Van Stalle, J. (1982) Scientific results of the Belgian Mount-Cameroon expedition (February-April 1981). III. Fam. Cixiidae, Derbidae, Meenoplidae, Dictyopharidae, Achilidae, Lophopidae, and Tettigometridae (Homoptera Fulgoroidea). Bulletin de l'Institut royal des Sciences naturelles de Belgique, Entomologie, 54 (6): 1-18. [Description of Patara leopoldi].

Van Veen, J. E. (1936) Die Cytheridae der Maastrichter Tuffkreide und des Kunrader Korallenkalkes von Süd-Limburg. IV. Die Gattungen Cythereis, Archicythereis und Cytherideis. Natuurhistorisch Maandblad, 11-12: 131-168. [Description of Cythereis reginae-Astrid].

Vermeersch, X. H. C. \& Vanslembrouck, A (2019) Update on the poorly know praying mantis Tamolanica leopoldi (Werner, 1923) with description of the previously unknown male. Belgian Journal of Entomology, 90: 1-13.

Vitali-di Castri, V. (1962) La familia Cheiridiidae (Pseudoscorpionida) en Chile. Investigaciones zoológicas chilenas, 8: 119-142. [Description of Apocheiridium leopoldi].

Voss, E. (1934) Bemerkungen zu einigen Indomalayischen Curculioniden (Col. Curc.) (54. Beitrag zur kenntnis der Curculioniden). Bulletin du Musée royal d'Histoire naturelle de Belgique, 10 (29): 1-4. [Description of Pachyrrhynchus speciosus subsp. samarensis f.n. regi].

Watson, A., Fletcher, D. S. \& Nye, I. W. B. (1980) The generic names of moths the world. Volume 2. London (Trustees of the British Museum (Natural History)): 1-228. <https://doi.org/10.5962/bhl.title.119421>.

Weber-Van Bosse, A. (1932) Résultats scientifiques du voyage aux Indes Orientales Néerlandaises de LL.AA.RR. le Prince et la Princesse Léopold de Belgique: Algues. Mémoires du Musée royal d'Histoire naturelle de Belgique, 6 (1): 1-27. [Description of Ostreobium Brabantium].

Werner, F. (1931) Résultats scientifiques du voyage aux Indes Orientales Néerlandaises de LL.AA.RR. le Prince et la Princesse Léopold de Belgique: Heterometabola I, Mantidae. Mémoires du Musée royal d'Histoire naturelle de Belgique, 4 (1): 33-38. [Description of Parhierodula leopoldi]. 
Werner, F. (1934) Mantides et phasmides recueillis dans les Indes Orientales. Bulletin du Musée royal d'Histoire naturelle de Belgique, 10 (22): 1-5. [Description of Calvisia leopoldi].

Willemse, C. (1933) Résultats scientifiques du voyage aux Indes Orientales Néerlandaises de LL.AA.RR. le Prince et la Princesse Léopold de Belgique: Heterometabolla III, Orthoptera II: Tettigoniidae and Gryllacridae. Mémoires du Musée royal d'Histoire naturelle de Belgique, 4 (8): 3-15. [Description of Pseudonicsara Leopoldi].

Witte, G. F., de (1929) Note préliminaire sur les Batraciens recueillis aux Indes Orientales Néerlandaises par S.A.R. le Prince Léopold de Belgique. Annales de la Société royale zoologique de Belgique, 60: 131-133. [Description of Asterophrys leopoldi].

Witte, G. F., de (1941) Batraciens et Reptiles. In: Exploration du Parc National Albert, Mission G.F. de Witte (19331935), 33: 1-261. [Description of Melanocalamus Leopoldi].

Zapfe, H. (1962) Caponina leopoldi nueva especie de Caponiidae (Araneae). Investigaciones zoológicas chilenas 8: 3-5. [Description of Caponina leopoldi].

Submitted: 15 February 2021. Accepted: 7 June 2021. Published: 28 September 2021.

Corresponding Editor: Alain Dubois. 